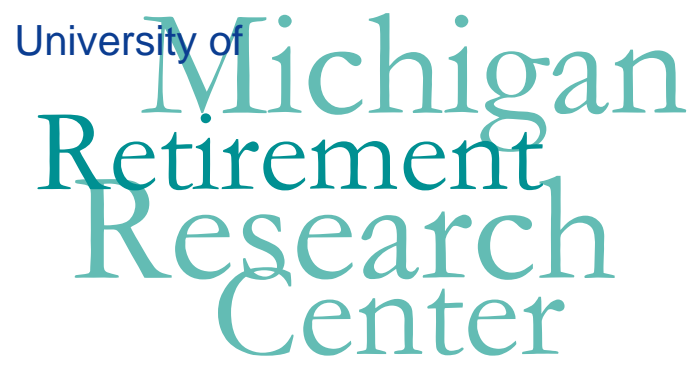

Working Paper

WP 2006-145

How the Distribution of After-Tax Income Changed Over the 1990s Business Cycle: A Comparison of the United States, Great Britain, Germany and Japan

Richard V. Burkhauser, Takashi Oshio, and Ludmila Rovba

\begin{tabular}{|l|l|l|}
\hline $\mathrm{M}$ & $\mathrm{R}$ \\
\hline $\mathrm{R}$ & $\mathrm{C}$ & \\
\hline
\end{tabular}$\quad$ Project \#: UM05-S3 


\title{
"How the Distribution of After-Tax Income Changed Over the 1990s Business Cycle: A Comparison of the United States, Great Britain, Germany and Japan”
}

\author{
Richard V. Burkhauser \\ Cornell University \\ Takashi Oshio \\ Cornell University \\ Ludmila Rovba \\ Cornell University
}

December 2006

\author{
Michigan Retirement Research Center \\ University of Michigan \\ P.O. Box 1248 \\ Ann Arbor, MI 48104 \\ http://www.mrrc.isr.umich.edu/ \\ (734) 615-0422
}

\section{Acknowledgements}

This work was supported by a grant from the Social Security Administration through the Michigan Retirement Research Center (Grant \# 10-P-98358-5). The findings and conclusions expressed are solely those of the author and do not represent the views of the Social Security Administration, any agency of the Federal government, or the Michigan Retirement Research Center.

Regents of the University of Michigan

David A. Brandon, Ann Arbor; Laurence B. Deitch, Bingham Farms; Olivia P. Maynard, Goodrich; Rebecca McGowan, Ann Arbor; Andrea Fischer Newman, Ann Arbor; Andrew C. Richner, Grosse Pointe Park; S. Martin Taylor, Gross Pointe Farms; Katherine E. White, Ann Arbor; Mary Sue Coleman, ex officio 


\title{
How the Distribution of After-Tax Income Changed Over the 1990s Business Cycle: A Comparison of the United States, Great Britain, Germany and Japan
}

\author{
Richard V. Burkhauser, Takashi Oshio, and Ludmila Rovba
}

\begin{abstract}
Using kernel density estimation we find that, over their 1990s business cycles, the entire distribution of after-tax household size-adjusted income moved to the right in the United States and Great Britain while inequality declined. In contrast, Germany and Japan had less income growth, a rise in inequality and a decline in the middle mass of their distributions that spread mostly to the right, much like the United States experienced over its 1980s business cycle. In the United States and Japan, younger persons fared relatively better than older persons while the opposite was the case in Great Britain and Germany.
\end{abstract}

\section{Authors’ Acknowledgements}

This work was in part supported by a Steven H. Sandell Dissertation Grant from the Social Security Administration through the Michigan Retirement Research Center to Rovba. The opinions and conclusions are solely those of the authors and should not be considered as representing the opinions or policy of the Social Security Administration or any agency of the Federal Government. The Japanese data from the Survey on Income Redistribution were made

available to Takashi Oshio by the Japanese Ministry of Health, Labour and Welfare. The notice number No.0822005 is dated August 22, 2005. The data processing was done by Takashi Oshio. 


\section{Introduction}

Using kernel density estimation, Burkhauser, Cutts, Daly, and Jenkins (1999) confirm previous studies showing that income inequality measured in pre-tax, post-transfer household size-adjusted income increased in Great Britain and the United States over the business cycle of the 1980s while the middle of their distributions decreased. But they also find that while the mass in both tails of their distributions increased significantly, by far the greatest gains were in the upper tail. So, income inequality increased primarily because the middle of their distributions got richer at different rates, rather than because a large part of the middle of their distributions became poorer. In this paper we update this work by looking at how these two countries as well as Germany and Japan fared over the 1990s business cycle. ${ }^{1}$

Based on summary income inequality measures, cross-national studies using data from the Luxembourg Income Study show that post-tax, post-transfer income inequality (that is, household size-adjusted income measured after taxes) in Japan was not only substantially below that of the United States at the start of the 1980s, but was also substantially below the level of income inequality found in European countries using post-tax, post-transfer measures of income (Atkinson, Rainwater, and Smeeding, 1995; Jacobs, 2000). But income inequality in Japan has increased since then (Atkinson, Rainwater and Smeeding, 1995; Fukawa, 2002; Jacobs, 2000; Smeeding, 1997; Tachibanaki, 1996 and Terasaki, 2002). By the middle of the 1990s, Japanese after-tax income inequality as measured by the Gini coefficient, while still substantially below the United States, was at the income inequality level of European countries (Smeeding, 1997).

What is not known is how the shape of the after-tax income distribution in Japan and these other countries changed over this period. Did the middle of the Japanese, German, and British income distributions fall, as was the case in the United States in the 1980s, with most of their middle class becoming richer? How did vulnerable populations - particularly older 
persons - fare relative to the rest of the population? In this paper, we answer these questions looking at after-tax income in four major industrialized OECD countries, and how it changed over their 1990s business cycles. We extend the existing literature on cross-national research of economic well-being by comparing the growth and dispersion of household size-adjusted aftertax income through the 1990s in the United States with that of three other major industrialized countries - Great Britain, Germany, and Japan. In doing so, we recognize that both after-tax income and income inequality vary over the business cycle. ${ }^{2}$

Since we are interested in making cross-national comparisons, and because taxes play a much larger role in our other three countries than in the United States, we measure household income net of income taxes and Social Security contributions in all countries. The CPS did not directly question its respondents about their federal income tax payments. We develop an income tax estimation procedure using a TAXSIM model that approximates the income tax burden and that can be used with consistently top-coded income variables in CPS for the years 1979 through 2000. After-tax income for Germany and Great Britain come from the Cross-National Equivalent File (CNEF), while after-tax income for Japan comes from the Survey of Income Redistribution (SIR).

\section{Data}

For the United States, we use data from the March Current Population Survey’s Annual Social and Economic Supplement (CPS), for Germany and Great Britain we use data from the Cross-National Equivalent Files (CNEF) prepared at Cornell University (Burkhauser, Butrica, Daly and Lillard, 2001), and for Japan, we use data from the Survey on Income Redistribution (SIR) to compare longer term trends in average after-tax income and after-tax income inequality in each of these major OECD countries. We separate the cyclical factors that influence yearly fluctuations from longer secular changes by comparing peak years of the 1990s business cycle in 
each country. Since each country's business cycle peaks occurred over slightly different years, the calendar years we compare will differ slightly across countries.

We consider CPS years 1980 through 2001 to calculate the household size-adjusted aftertax income of individuals living in United States households. ${ }^{3}$ There have been two major business cycles over this period. While we use data from all years, we focus most of our comparisons on peak business cycle years 1979, 1989, and 2000.

We consider income years 1990-2000 for Great Britain and income years 1991-2001 for Germany to capture their full business cycles. To do so, we use the February, 2004 version of the CNEF. While we use data from all years, we focus most of our comparisons on peak years 1990 and 2000 for Great Britain and 1991 and 2001 for Germany. A major advantage of the CNEF data is that it provides harmonized measures of household income before and after the impact of the government tax-and-transfer systems in Germany and Great Britain, based on the German Socio-Economic Panel (GSOEP) and the British Household Panel Survey (BHPS). These are both representative household panels of their countries.

The CNEF data include standard demographic information, household income and its components, and individual data on employment and labor earnings. Also included are crosssectional and longitudinal sample weights, and macroeconomic indicators for each country. Households from the eastern states of Germany were included in the German data beginning with income year 1989. We use the CPS data here rather than the CNEF equivalized values from the Panel Study of Income Dynamics since we want to compare our results to Burkhauser, Couch, Houtenville and Rovba (2004) and more importantly because the CPS provides much greater sample sizes.

We consider income years 1989-2001 for Japan to capture their full business cycle. To do so we use cross-sectional data from the Survey on Income Redistribution (SIR), conducted by the 
Ministry of Health and Welfare of Japan every three years. The SIR data set is also one of the most reliable income surveys in Japan. It collects information on household income and its sources such as social security income including public pensions, medical care, and family allowances, and the Ministry estimates tax payments for its households. We use micro-data from SIRs released in 1990 and 2002 that collect income data for the previous year. The sample sizes range between 7,165 (in 1984) and 8,856 (in 1990). (Income values for all years of our country data sets are available from authors upon request.)

Since most measures of income inequality are sensitive to outliers, we exclude observations in the top and bottom two percent of the household size-adjusted income distribution in Germany, Great Britain, and Japan. For the United States we use the consistent top coding convention discussed in Burkhauser, Butler, Feng and Houtenville (2004), Burkhauser, Couch, Houtenville and Rovba (2004), and Feng, Burkhauser, and Butler (2005) to control for outliers. $^{4}$

\section{Measuring Economic Well-Being}

All income calculations are based on the household post-tax post-transfer income. That is, income from all sources (labor earnings, income from investments and savings, public and private pensions, and transfers) minus total household taxes and social insurance contributions. Our measure of post-tax post-transfer income does not include non-money transfers such as food stamps, health benefits, subsidized housing, payments in kind, or fringe benefits from one's employment.

To control for differences in the number of people living in a household and hence the share of household income they control, it is important to take into consideration economies of scale associated with joint residence. How much income sharing occurs among household members is a matter of some debate, as is the economies of scale associated with shared living 
within a household. We assume a scale elasticity of 0.5. Burkhauser, Smeeding and Merz (1996) note that this is the dominant one used in the cross-national literature. ${ }^{5}$

Sharing Unit. The CPS family definition, based on marriage or blood relationship, is often used as the income-sharing unit in the United States income distribution literature, but the CPS household definition, based on common residence, is closer to what is used in most crossnational studies. It is the one we use here for the United States. The BHPS and GSOEP sharingunit definitions fall somewhere between the CPS family and common residence definitions in that they include unmarried non-blood-related cohabitants in the "family" but exclude other unmarried non-blood-related residents. For convenience of discussion, we use the word "household" to describe the British and German sharing units in our analysis, although they only approximate the CPS household definition. In the SIR for Japan, household is defined in a manner similar to the CPS — as all persons sharing the same housing unit, regardless of any familial relationship. Adjusting for inflation. While summary measures of the income distribution used here (90/10 ratio and Gini coefficients) are insensitive to the fluctuations in the units of the currency, as is the shape of the income distribution, comparisons of real changes in average income and in the movement of the income distribution over time are sensitive to these fluctuations. Here we use the Consumer Price Index-X (CPI-X) to adjust for inflation in the United States because it is the official measure of inflation used by the United States Bureau of the Census. ${ }^{6}$

We use the International Monetary Fund Consumer Price Index for Germany, Great Britain and Japan. All incomes are converted to 2000 monetary units.

Defining the Older Population. Our age dichotomy is somewhat arbitrary. We divide our total sample into persons aged 65 and over and persons younger than age 65 .

Accounting for taxes. Household income is defined as the sum of all income held by individuals residing in a single dwelling, and it is measured as post-tax, post-transfer money 
income. In the U.S. literature, pre-tax, post-transfer family money income, including cash government transfers, is the most common yardstick used to measure economic status. However, we are interested in making cross-national comparisons, and because taxes play a much larger role in Germany, Great Britain, and Japan than in the United States, we measure household income net of income taxes and Social Security contributions in all countries. After-tax income provides a more accurate measure of the living standards attained by individuals and households.

Estimating Income Tax Burdens for Current Population Survey (CPS) Households. The CPS did not directly question its respondents about their federal income tax payments. Rather, Unicon Group at RAND simulated these payments. However, the RAND simulations of tax payments did not adjust reported income for changes in top coding. The CPS top codes all sources of income (e.g. wages and salaries, interest, etc.). Since the nominal income of the population rises each year, the share of the income distribution that is affected by top coding will change. This is also the case when the Census Bureau periodically changes the nominal value of the top codes. As a result, taxes simulated by RAND are not adjusted for differences in top coding over time. To address this issue, we impose consistent top coding solutions on each source of income, and sum over each of these sources to generate our measure of an individual's income in a given year. We do this by top coding income at the same percentile of the income distribution from that source for all years. That is, we determine in which year the largest portion (lowest percentile) of the income distribution from that source was affected by this censoring, then top code all years to reflect that portion for each source of income. In this way, all sources of income are consistently top coded at the same point in the distribution in all years (See Burkhauser, Couch, Houtenville, and Rovba, 2004 for a more detailed discussion of this process and a table showing the income sources, share of the population affected by the top code and the most constrained year). ${ }^{7}$ 
We develop an alternative federal income tax estimation using the National Bureau of Economic Research TAXSIM Model that approximates the income tax burdens available in the CPS for the years 1979 through 2000 and that can be used with consistently top-coded income variables in CPS to estimate income tax burdens. See the Data Appendix for details.

\section{Trends in Income and Income Inequality}

Table 1 shows United States, British, German, and Japanese mean and median after-tax income as well as the 90/10 ratio and Gini values for the peak years of their respective business cycles for the entire population and for older and younger persons. (Income and inequality values for all years are available from the authors upon request, as are pre-tax, post-transfer values.)

For the United States after-tax income (both mean and median) increased over both the 1980s and 1990s business cycles. Real mean household size-adjusted after-tax income increased by 10.93 percent over the 1980 s (Column 4) and by 7.27 percent over the 1990 s while median after-tax income increased by 5.95 percent and 7.10 percent respectively over these periods. Hence, average after-tax income increased substantially over both United States business cycles. But after-tax income growth was much more equally shared in the 1990s than in the 1980s. Income inequality rose substantially over the business cycle of the 1980s whether measured by the 90/10 ratio (23.67 percent) or by the Gini coefficient (14.17 percent). In contrast, income inequality fell over the 1990s business cycle whether measured by the 90/10 ratio (-6.82 percent) or the Gini coefficient (-2.24 percent) (Burkhauser, Couch, Houtenville and Rovba, 2004 and Burkhauser and Rovba 2005, using before-tax income, find similar trends).

Real after-tax income increased even more in Great Britain over the 1990s than in the United States measured by mean (20.61 percent) or median (20.84 percent) and after-tax income inequality fell measured by the 90/10 ratio (-6.78 percent) or the Gini coefficient (-3.59 percent). In contrast, while real after-tax mean (median) income in Germany increased by about the same 
amount as in the United States, 7.07 percent (5.62 percent), after-tax income inequality grew dramatically whether measured by a change in the $90 / 10$ ratio (9.59 percent) or in the Gini coefficient (8.18 percent). As a result, after-tax income inequality in Germany, which was substantially below after-tax income inequality in Great Britain at the beginning of the 1990s business cycle, was approximately equal to it at the end. But the level of after-tax income inequality in both Great Britain and Germany still was considerably below the level of after-tax income inequality in the United States. In Japan, mean (median) real income increased over the 1990s by 6.04 (5.73) percent, while the magnitudes of the percentage changes in income inequality were near those experienced in Germany during the 1990s. As a result Japan moved closer to the levels of income inequality in the United States than to those in Great Britain and Germany by the end of the period.

As Table 1 shows, changes in after-tax income levels and within-group income inequality of older and younger persons also varied considerably across the four countries. Mean (median) after-tax income of older persons in the United States grew dramatically over the 1980s business cycle both absolutely—19.95 (16.96) percent — and relative to younger persons — from 83.3 to 90.7 (see last row of columns 1 and 2). While real mean (median) after-tax income was higher at the end of the 1990 business cycle than at the start—it grew by $2.31(5.45)$ percent — the mean after-tax income of older persons fell relative to younger persons-from 90.7 to 86.0 (see last row of columns 2 and 3). In Japan, over the business cycle of the 1990s, relative after-tax income of older persons fell from 94.1 to 89.8 percent. In contrast, the average real after-tax income of older persons in both Great Britain and Germany grew substantially over the 1990s business cycle and relative to their younger populations (last row of columns 6 and 7 and 9 and 10). In all four countries, after-tax income inequality fell among older persons over the 1990s. In the United States this decline was in sharp contrast to substantial increases over the 1980s. 
The growth in the average after-tax income of younger people over both United States business cycles was approximately the same. Average after-tax income also increased at younger ages in Great Britain, Germany, and Japan in the 1990s. But the changes in after-tax income inequality among younger persons in the four countries were quite different over their 1990s business cycles. Unlike the substantial increases in after-tax income inequality experienced among younger persons in the United States in the 1980s, after-tax income inequality among younger persons in the United States fell as measured by both the $90 / 10$ ratio (-7.61 percent) and Gini coefficient (-2.10 percent) in the 1990s. In Great Britain, after-tax income inequality also fell substantially over the 1990s business cycle, while in Germany and Japan it rose substantially among younger persons. By the end of their 1990s business cycles, there was about the same level of after-tax inequality among younger persons in Germany as was the case for younger people in Great Britain.

Comparing after-tax income values and relevant measures of inequality in Table 1 to pretax post-transfer incomes and corresponding 90/10 ratio and Gini coefficients in Appendix Tables 1A and 2A, we observe the inequality reducing effect of taxation: post-tax post-transfer income inequality is lower than pre-tax post-transfer income inequality, whether measured by $90 / 10$ ratio or Gini coefficient, for every sub-population and country in our analysis. Taxes also have a moderate equalizing effect on relative well-being of older populations. While the mean pre-tax post-transfer income of older persons relative to younger persons, for instance, in the United States in 2000 is 75.6 percent, the corresponding figure for post-tax post-transfer income is 86.0 percent. Similar findings apply to our other three countries.

\section{Measuring Changes in the Income Distribution Using Kernel Density Estimation}

Table 1 uses summary measures of the after-tax income distribution to show first, that after-tax income growth in the United States were more equitably distributed over the business 
cycle of the 1990s than the business cycle of the 1980s and second, that while the United States and Great Britain experienced substantial economic growth in the 1990s while decreasing aftertax income inequality, Germany and Japan did so with substantial increases in after-tax income inequality. We now more fully explore how the distribution of after-tax income changed in each of these countries by estimating the probability density function of household size-adjusted aftertax income of their populations using Epanechnikov kernels with adaptive bandwidths. Kernel estimators are well established in the statistics and econometrics literatures, see: Silverman (1986). For a technical discussion of the kernel density method employed here in the context of measuring economic well-being, see Burkhauser, Cutts, Daly and Jenkins (1999) and Burkhauser, Couch, Houtenville and Rovba (2004).

Figure 1 shows that in 1979 the distribution of after-tax income in the United States had the traditional inverted $\mathrm{U}$ shape with the great mass of the population bunched around the mode of the distribution. But by the end of the 1980s business cycle in 1989, the distribution had become much flatter. The middle mass of the distribution around the mode fell (fewer people were in the middle of the distribution) with the vast majority spilling toward the higher tail of the distribution and a much smaller but still important group spilling toward the lower tail of the distribution. ${ }^{8}$

However, between the two peak years of the 1990s business cycle, 1989 and 2000, the entire United States after-tax income distribution moved to the right. More formally, the income distribution in 2000 attained first order stochastic dominance over the 1989 distribution. ${ }^{9}$ At every percentile of the 2000 distribution, the level of income is higher in 2000 than in 1989 , the previous business cycle peak year. While not everyone gained at the same rate, everyone in the distribution gained. 
Figure 2, shows the after-tax income distribution of the older United States population. In 1979 the distribution has the traditional inverted U shape with an even greater mass of the population bunched near the mode. As was the case for the more general population, by 1989 the middle mass fell with the vast majority becoming unequally richer. Over the 1990s business cycle there was much less movement overall. The smaller decline in the middle mass around the mode of the distribution spilled only somewhat to the right, creating a bulge in the distribution.

Figure 3 shows the after-tax income distribution of the younger United States population. In 1979, the distribution has the traditional inverted U shape and is closer in shape to the overall population than was the distribution for the older population in Figure 2. This is also the case for the 1989 and 2000 distributions. Over the 1980s business cycle, the middle mass around the mode spilled primarily into the upper tail, but the entire distribution moved to the right over the 1990s business cycle.

Figures 4, 5 and 6 capture the change in the after-tax income distribution for Great Britain over their 1990s business cycle. As Table 1 showed, Great Britain experienced substantial economic growth. Figure 4 shows that the 2000 after-tax income distribution attained first order stochastic dominance over the 1990 distribution. Furthermore, the noticeable second hill in the 1990 distribution is considerably smoother in the 2000 distribution. The older (Figure 5) and younger (Figure 6) populations also shifted to the right over the 1990s business cycle. In all three populations, while the mode values declined, a far larger proportion of the distribution remained bunched near the middle of the distribution than was the case in the United States. Nonetheless, the after-tax income distribution movements in Great Britain and the United States were very similar over their 1990s business cycles. This stands in stark contrast to the movement in the after-tax income distribution in Germany and Japan over their 1990s business cycles. 
In 1991, the beginning year of the German business cycle, their after-tax income distribution (Figure 7) had the traditional inverted $\mathrm{U}$ shape with the great mass of the population near the mode of the distribution. But unlike the United States or Great Britain, the after-tax income distribution in Germany at the end of their 1990s business cycle in 2001 did not attain first order stochastic dominance over the 1991 income distribution. Rather, like the United States in the 1980s, the mass of the population near the mode of the distribution fell with the vast majority of people spilling to the right and becoming richer and a smaller but important share becoming poorer.

While Figure 8 shows that the after-tax income distribution of the older German population at the end of the 1990s business cycle, like that of Great Britain's, did attain first order stochastic dominance over the distribution at the beginning of the business cycle, Figure 9 shows that the spillage of the middle mass away from the mode of the after-tax income distribution for younger Germans over the 1990s business cycle more closely resembled the movement for younger persons in the United States over their 1980s business cycle with a small but important group becoming poorer.

The after-tax income distribution in Japan at the end of their 1990s business cycle in 2001 also did not attain first order stochastic dominance over the after-tax income distribution at the beginning of the business cycle in 1989. Figure 10 shows that by the end of the 1990s business cycle, the overall after-tax income distribution in Japan had become much flatter. The middle mass of the distribution around the mode fell with the majority spilling toward the higher tail of the distribution and a very small group spilling toward the lower tail of the distribution.

While Figure 11 shows that the movement in the after-tax income distribution of the older Japanese population comes very close to achieving first order stochastic dominance over the 1990s business cycle, Figure 12 shows that the spillage of the middle mass away from the mode 
of the after-tax income distribution for younger Japanese closely resembled that of younger persons in the United States over the 1980s business cycle and younger persons in Germany over the 1990s business cycle. In all three cases, a small but important segment of the younger population became poorer.

Kolmogorov-Smirnov Tests of the Significance of Distributions Shifts. We use the Kolmogorov-Smirnov statistic to test whether the shifts in the distributions described above were statistically significant. This test considers the null hypothesis that the distribution in one period is equal to the distribution in another period or $\mathrm{H}_{0}: \mathrm{F}_{1}(\mathrm{x})=\mathrm{F}_{2}(\mathrm{x})$. In practice, the cumulative distribution functions $\mathrm{F}_{1}(\mathrm{x})$ and $\mathrm{F}_{2}(\mathrm{x})$ may be calculated directly from the data or from the estimated kernel densities. We use the empirical cumulative distribution functions in our tests since they are easier to calculate and do not depend on our choice of kernel or bandwidth.

Table 2 provides calculations of the Kolmogorov-Smirnov statistic for the pair-wise comparisons over the years covered by our study for the four countries. For the United States population we compare the 1979 and 1989 distributions, the 1989 and 2000 distributions, and the 1979 and 2000 distributions. For Great Britain, we compare the 1990 and 2000 distributions. For Japan we compare 1989 and 2001 distributions and, for Germany, the 1991 and 2001

distributions. All tests indicate that the changes in the income distribution are statistically significant at the 1 percent level. Thus, we find statistically significant changes in the overall after-tax income distribution between peak-to-peak business cycle years in all four countries for the entire population, as well as for older and younger individuals.

\section{Tracking the Disappearing Middle Of the After-Tax Income Distribution}

We use a test based on the binomial distribution to more precisely examine how the spillage out of the middle of the after-tax income distribution in the United States over the 1980s business cycle and in Germany and Japan over the 1990s business cycle was distributed between 
the two tails of the distribution. To do so we first define the left and the right tails of the distribution. In the United States, for 1979 and 1989 after-tax income densities, we define the left intersection, and the left tail, as the point in the distribution of household size-adjusted real aftertax income at which the empirical after-tax income density in 1989 drops below the empirical after-tax income density in 1979 . As can be seen in Figure 1, this intersection point is at $\$ 7,812$ for the entire population. The right intersection point, which defines the start of the right tail, is the point in the distribution of household size-adjusted real after-tax income at which the income frequency density in 1989 rises above the after-tax income frequency density in 1979. This intersection point is at $\$ 31,693$ for the entire population. The intersections for other pairs of densities are defined in a similar way. (See Figures 3, 7, and 9.)

Table 3 shows the proportion of the population contained in the left tail, middle and right tail as defined by the peak-to-peak year density function intersections for the United States (columns 1 and 2) and Germany (columns 5 and 6) and Japan (columns 9 and 10) and their standard errors. ${ }^{10}$

In the United States, 7.18 percent (column 3) of the entire distribution slid out of the middle of the distribution over the 1980 s business cycle. But the vast majority of that 7.18 percent (82.46 percent) became richer.

Over the German business cycle of the 1990s an even greater percentage of the middle mass around the mode of the distribution ( 8.23 percent) slid into the two tails. But once again the vast majority ( 88.58 percent) became richer. In Japan, over the 1990s business cycle, 6.18 percent of the middle mass moved to the tails, mostly to the right tail ( 93.20 percent). Nonetheless, in the United States (17.54 percent), in Germany (11.42 percent), and in Japan (6.80 percent) a small minority became poorer as after-tax income inequality rose in these countries. 
Table 3 shows that the movement out of the middle for young persons was even greater in the United States (7.87 percent), Germany (10.99 percent), and Japan (8.65 percent) than for the population as a whole. Furthermore, the share of the middle that dropped into the left tail was also greater in the United States (26.18 percent), Germany (22.47 percent), and Japan (14.22).

Nonetheless, in all countries the overwhelming majority of the increase in inequality was caused by younger people becoming unequally richer.

Significance Tests of Changes in the Tails of the Distribution. We test the statistical significance of the density changes in the tails of the after-tax income distribution reported in column 3 for the United States, column 7 for Germany, and column 11 for Japan using a binomial-based test statistic to determine whether the density masses contained in the left (or right) tails of two distributions differ. Specifically, letting $p_{1}$ and $p_{2}$ denote the probability that a randomly chosen individual will have an income in the tail of the distribution in years 1 and 2, respectively, we test whether these two proportions are the same using $Z_{p}=\frac{\hat{p}_{1}-\hat{p}_{2}}{\sqrt{V\left(\hat{p}_{1}\right)+V\left(\hat{p}_{2}\right)}}$.

The variances of the estimated proportions are given by $V\left(\hat{p}_{i}\right)=\hat{p}_{i}\left(1-\hat{p}_{i}\right) \sum_{j=1}^{n} \frac{w_{i j}^{2}}{n_{i}^{2}}$, for each year $i$ $=1,2$. The $Z_{p}$ statistic is asymptotically distributed standard normal. For all pair-wise comparisons, we strongly reject the null hypothesis that the masses in the tails are the same for our paired years.

\section{Conclusion}

We find major differences in how after-tax income growth was distributed within our four countries over their 1990s business cycles. The real household size-adjusted after-tax income distributions of the United States and of Great Britain at the end of their 1990s business cycle achieved first order stochastic dominance over their after-tax income distributions at the 
beginning. This was a dramatic change from what had happened in both countries in the 1980s. Burkhauser, Crews, Daly and Jenkins (1999) first showed using before-tax income, and we confirm here using after-tax income, that over the 1980s business cycle, the middle of the United States income distribution fell, with the vast majority of people becoming unequally richer, and a statistically significant but relatively small share becoming poorer. Burkhauser, Crews, Daly and Jenkins (1999) report similar findings with respect to before-tax income for the United Kingdom over their 1980s business cycle. Hence, unlike their experiences in the 1980s, all people in the United States and Great Britain shared the gains of economic growth in the 1990s. Moreover, in contrast to the 1980s, measured after-tax income inequality fell both in the United States and in Great Britain over this period.

In contrast, measured after-tax income inequality in Germany and Japan grew substantially over their 1990s business cycles. Like the United States in the 1980s, the middle mass of the distribution fell around the mode. While the greatest share of the middle mass slid to the right, as people became unequally richer, a statistically significant but smaller share became poorer. More remarkably, the relative movement out of the middle and into the two tails in Germany and Japan is very similar in magnitude to that of the United States over the 1980s. About 83 percent of the decline in the middle in the United States over the 1980s was accounted for by people becoming richer while about 89 percent was accounted for by a movement to the right in Germany and about 93 percent by a movement to the right in Japan.

In all four countries, the average household size-adjusted real after-tax income of older persons grew in the 1990s but the growth in Great Britain and in Germany was greater both absolutely and relative to their younger populations. And in all four countries after-tax income inequality fell among their older populations over the period. 
While the average household size-adjusted after-tax income of younger persons also grew in all four countries over the 1990s, only in the United States were the gains greater among this population. It was in this subpopulation that the differences in how after-tax income growth were shared are greatest across the four countries. In both the United States and Great Britain the aftertax income distribution among younger people at the end of the 1990s business cycle achieved first order stochastic dominance over their income distribution at the start, while this was not the case in Germany and Japan. In the United States and Great Britain after-tax income inequality fell and in Germany and Japan it increased. In Germany, the middle mass of the after-tax income distribution of their younger population fell with the vast majority spilling to the right. But a statistically significant but small share fell to the left. Once again the comparison with events in Germany and Japan in the 1990s and the United States in the 1980s are remarkably similar. In the United States 74 percent of the decline is explained by younger people becoming richer. In Germany 78 percent of the decline is so explained. In Japan 86 percent of the decline is so explained.

This paper has focused on measuring what have been quite different changes in the aftertax income distributions of four major OECD countries over their 1990s business cycles. The causes for these differences are not clear. In the United States, the confluence of significant economic growth and work-based welfare reforms dramatically improved the employment and economic well-being of single women with children relative to the rest of the population and more generally did so for lower-skilled workers. This may in part explain why economic growth in the 1990s was more equally shared in the United States than it was in the 1980s. ${ }^{11}$

In Germany it may be that reunification, which occurred in 1989 , not only dramatically changed the population of Germany relative to the population living in the former western states of Germany but may have changed the political and economic makeup relative to that in the pre- 
unification western states. This paper is capturing the changes in the income distribution over reunified Germany's first business cycle. It remains to be seen if this is simply a short term outcome that was inevitable given the significantly unequal market skills of the eastern and western states' populations that will quickly fade away, or whether this is only the first round of a much longer term trend in a country where the greater inequality in market skills created with unification will continue to yield increases in income inequality for generations to come.

Post-World War II Japan has long been characterized as a homogeneous society and one with a relatively low degree of income inequality (Vogel 1979, Tachibanaki, 2005). But the rise in inequality over its 1990 s business cycle suggests that by 2001, Japan could no longer be thought of as a "90 percent middle-class society" (Tachibanaki, 2005). By 2001 the level of after-tax income inequality in Japan was closer to that of the United States than to Germany or Great Britain. The exact causes of this increase are not clear, but they may result from a complex interplay of demographic and economic factors, including population aging, greater heterogeneity in generational configurations within households, and most importantly the fuller emergence of a market-oriented economy, including a shift from a lifetime employment/seniority wage system to a more performance-based one. Finally, the steep rise in land and share prices during the "bubble economy" of the late 1980s and its subsequent fall over the 1990s may have increased inequalities in the distribution of assets.

This paper used kernel density estimation to look behind summary measures of after-tax income inequality to see how the entire distribution of after-tax income shifted over the 1990s business cycles in four major OECD countries. It distinguished between increases in inequality caused by the middle of the distribution falling into the two tails, from increases in inequality caused by the population as a whole becoming unequally richer. It did so because, other things equal, declines in after-tax income inequality are preferred to increases in after-tax income 
inequality. But increased inequality in a country where economic growth is making everyone richer is surely preferred to an outcome where the rich are getting richer at the expense of the rest of the population. 


\section{Appendix Table 1A. Pre-tax Post-transfer Household Size-Adjusted Income and Income Inequality, by Age in the United}

States, Great Britain, and Germany.

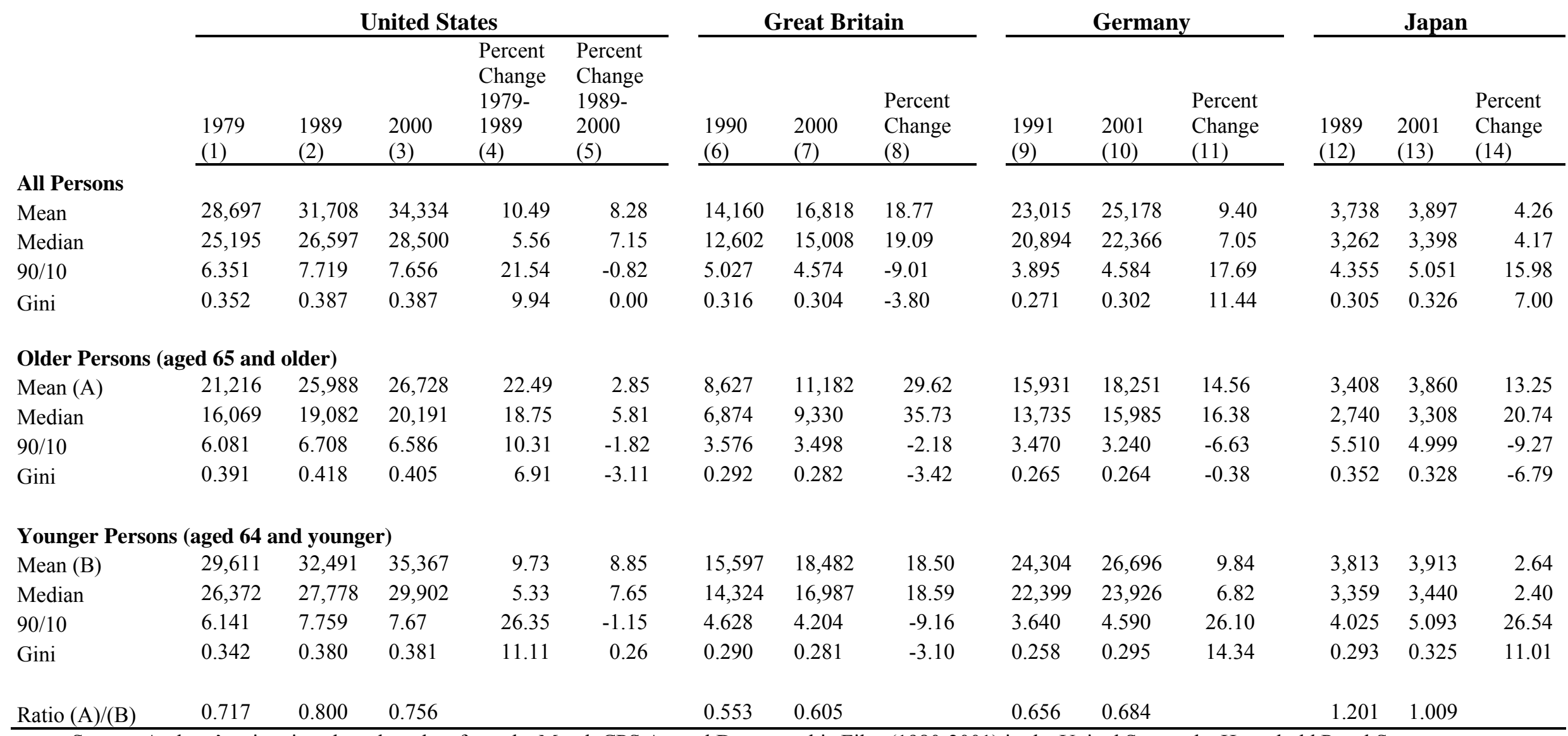

Source: Authors' estimations based on data from the March CPS Annual Demographic Files (1980-2001) in the United States, the Household Panel Survey

(1991-2001) in Great Britain, and the Socio-Economic Panel (1992-2002) in Germany.

Notes: $\quad{ }^{\mathrm{a}}$ Income values are in 2000 United States dollars

${ }^{\mathrm{b}}$ Income values are in 2000 British pounds

${ }^{\mathrm{c}}$ Income values are in 2000 euros 
Appendix Table 2A. Household Size-Adjusted Income and Income Inequality for Total Population, in the United States, Great Britain, and Germany.

\begin{tabular}{lllll}
\hline \multicolumn{5}{c}{ United States } \\
\hline & & $\begin{array}{l}\text { Percent } \\
\text { Change }\end{array}$ & $\begin{array}{l}\text { Percent } \\
\text { Change } \\
\end{array}$ \\
& & & $1979-$ & $1989-$ \\
1979 & 1989 & 2000 & 1989 & 2000 \\
$(1)$ & $(2)$ & $(3)$ & $(4)$ & $(5)$ \\
\hline
\end{tabular}

Mean

Median

$90 / 10$

Gini

$\begin{array}{lllll}22,494 & 24,954 & 26,767 & 10.93 & 7.27 \\ 20,892 & 22,135 & 23,707 & 5.95 & 7.10 \\ 4.71 & 5.82 & 5.42 & 23.67 & -6.82 \\ 0.301 & 0.344 & 0.336 & 14.17 & -2.24\end{array}$

Older Persons (aged 65 and older)

Mean (A)

Median

90/10

$\begin{array}{lllll}28,697 & 31,708 & 34,334 & 10.49 & 8.28 \\ 25,195 & 26,597 & 28,500 & 5.56 & 7.15 \\ 6.35 & 7.72 & 7.66 & 21.54 & -0.82 \\ 0.352 & 0.387 & 0.387 & 9.94 & 0.00\end{array}$

Gini

0.387

\section{All Persons}

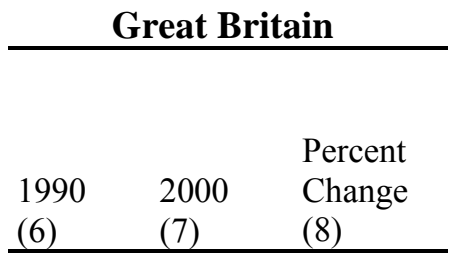

$\begin{array}{lll}11,539 & 13,917 & 20.61 \\ 10,583 & 12,788 & 20.84 \\ 3.89 & 3.63 & -6.78 \\ 0.274 & 0.264 & -3.59\end{array}$

$14,160 \quad 16,818 \quad 18.77$

$12,602 \quad 15,008 \quad 19.09$

$\begin{array}{lll}5.03 & 4.57 & -9.01\end{array}$

$\begin{array}{lll}0.316 & 0.304 & -3.8\end{array}$

Younger Persons (aged 64 and younger)

$\begin{array}{llllll}\text { Mean (B) } & 26,649 & 29,579 & 32,092 & 11 & 8.5 \\ \text { Median } & 23,805 & 24,945 & 26,647 & 4.79 & 6.82 \\ 90 / 10 & 17.93 & 20.23 & 16.37 & 12.86 & -19.07 \\ \text { Gini } & 0.4045 & 0.434 & 0.432 & 7.31 & -0.52\end{array}$

$\begin{array}{lll}12,959 & 15,069 & 16.28 \\ 11,882 & 14,030 & 18.08 \\ 15.71 & 16.76 & 6.68 \\ 0.391 & 0.393 & 0.51\end{array}$

Germany

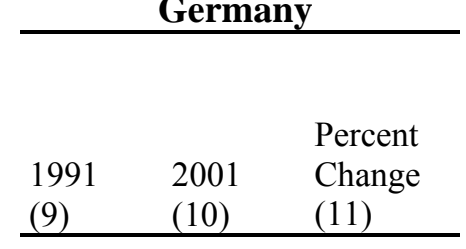

$\begin{array}{lll}17,377 & 18,605 & 7.07 \\ 16,146 & 17,054 & 5.62 \\ 3.10 & 3.39 & 9.59 \\ 0.231 & 0.25 & 8.18\end{array}$

$23,009 \quad 25,178 \quad 9.43$

$\begin{array}{lll}20,894 & 22,366 \quad 7.05\end{array}$

$\begin{array}{lll}3.89 & 4.58 & 17.74\end{array}$

$\begin{array}{lll}0.271 & 0.301 & 11.07\end{array}$

$\begin{array}{lll}19,615 & 20,620 & 5.12 \\ 18,681 & 18,685 & 0.02 \\ 46.17 & 73.14 & 58.41 \\ 0.388 & 0.44 & 13.40\end{array}$

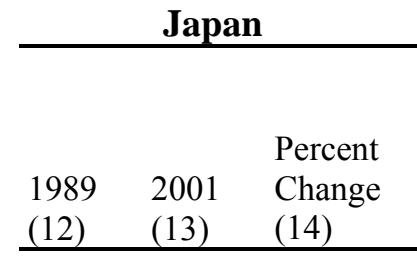

$\begin{array}{rrr}3,205 & 3,399 & 6.04 \\ 2,829 & 2,991 & 5.73 \\ 4.24 & 4.65 & 9.64 \\ 0.298 & 0.315 & 5.84\end{array}$

$3,738 \quad 3,897 \quad 4.26$

$3,262 \quad 3,398 \quad 4.17$

$\begin{array}{lll}4.35 & 5.05 & 15.98\end{array}$

$\begin{array}{lll}0.305 & 0.326 & 7.00\end{array}$

$\begin{array}{rrr}3,097 & 2,925 & -5.53 \\ 2,799 & 2,580 & -7.84 \\ 11.67 & - & - \\ 0.376 & 0.459 & 22.25\end{array}$

Source: Authors' estimations based on data from the March CPS Annual Demographic Files (1980-2001) in the United States, the Household Panel Survey (1991-2001) in Great Britain, and the Socio-Economic Panel (1992-2002) in Germany.

Notes: ${ }^{a}$ Income values are in 2000 United States dollars

${ }^{\mathrm{b}}$ Income values are in 2000 British pounds

${ }^{\mathrm{c}}$ Income values are in 2000 euros 


\section{Data Appendix: Estimating taxes from the CPS data using TAXSIM model}

The outline of this section is as follows. First, we discuss issues surrounding the estimation of income taxes and clarify some terms that are used throughout this paper. Next we talk briefly about the National Bureau of Economic Research (NBER) TAXSIM model. Then we discuss our methodology for creating and constructing TAXSIM input variables using CPS data. Also, we compare (a) the CPS tax estimates provided by Unicon with the TAXSIM tax estimates based on (b) raw public use CPS data and on (c) consistently top-coded data. Finally, we compare our CPS tax estimates with those obtained from PSID using TAXSIM that are widely used in economic research. We conclude that our TAXSIM estimates are a reasonable approximation to the CPS tax estimates for 1979 through 2000.

The CPS provides information on both family and individual income and resources. Both the CPS tax program and the National Bureau of Economic Research (NBER) TAXSIM program estimate the income taxes of tax units. What makes computing family income tax estimations difficult is that while families may share resources, families do not necessarily file taxes as families. It is possible that different groups within the family file taxes separately.

For this reason, to calculate a family tax burden it is necessary to first determine the number of tax units in a family and to then estimate each tax unit's burden separately. To do this one not only has to assign those with income to the appropriate tax unit but also assign dependents - with and without their own personal income - to the appropriate tax unit. In making our assumptions about tax filing units and dependent status, we use tax filing status variables provided by Unicon Group for each person in CPS. We assume the head and dependent spouse (regardless of whether the spouse has her own income source) are a single tax filing unit, each dependent with income (except the spouse) is a tax filing unit, and every nondependent family member (this can include married or unmarried persons who are blood relatives) is a tax filing 
unit. Dependents without income are assigned to the tax unit of their provider. In this way every individual within a family is assigned to a tax unit either as head of a tax unit, as a dependent within a tax unit, or both. The tax liabilities of within-family tax units are then summed to obtain the family tax liability.

Each tax unit is assigned one of four possible tax filing statuses. All legally married couples are assumed to file taxes jointly and their tax filing status is defined as "married." Together they file one joint tax return that captures the joint income of the married couple. Thus, married tax filing units can have one or two earners. The number of earners, however, is irrelevant because each married tax filing unit files only one joint tax return. We assume unmarried individuals with dependents file taxes as single persons and their tax filing status is defined as "head of household." Further, we assume unmarried individuals without dependents file taxes as single persons and their tax filing status is defined as "single." Finally, we assign dependents with income who appear on parents' tax return to a category "single dependent on parents return," therefore for everyone in this category no personal exemption can be claimed. Head of household or single tax filing units have only one income earner.

TAXSIM Model. The NBER TAXSIM model is a micro-simulation program that estimates both federal and state taxes for the United States. The program uses information on income and deductions to estimate tax liabilities. For more information on the TAXSIM model, see Feenberg and Counts (1993). While in this paper we compare the federal income tax burden estimates of the TAXSIM model with CPS tax program estimates, we have also calculated state income tax using the TAXSIM model as well as Social Security tax burdens for CPS families using our own programs. All these values are available upon request from the authors.

TAXSIM Input Variables. A number of input variables are required for the TAXSIM model. These variables are case identification number, tax year, state, tax filing status, number of 
dependent exemptions, number of age exemptions, wage and salary income, dividend income, other property income, pension, gross Social Security income, other transfer income, rent paid, property taxes paid, amount of itemized deductions, unemployment compensation, and child care expenses.

Constructing most of the income variables is straightforward since much of the data are already available in the CPS. However there are a few variables, such as tax filing status - the correct tax unit to which members of the family belong - and number of dependent exemptions, whose construction is more complicated. Tables $1 \mathrm{~B}$ and $2 \mathrm{~B}$ list the input variables required for the TAXSIM model and the CPS variables we used. This section of the paper discusses the assumptions we made in order to create these variables and how these assumptions compare to those made in the CPS.

Marital Status. For income and tax purposes, the CPS considers two persons to be married if they have been living together for at least a year, regardless of their legal marital status. Legal marital status of heads and partners can be established using information provided in the CPS. However, this information is not available for other family members. For the TAXSIM model we treat a non-married cohabiting head and his partner in the CPS data as two separate individual tax filing units rather than as members of a married tax filing unit. Federal and state tax laws do not permit non-married cohabiting individuals to file taxes jointly. For this reason we use information on legal marital status to assign individuals to tax units.

Tax Filing Status. The CPS staff calculated tax burdens for married couples, household heads, and single person tax units. In the CPS tax program, each married couple is assumed to file one tax return that represents the couple's joint income, regardless of their legal marital status. Individuals are assigned a tax filing status of head of household if: they are unmarried, divorced, separated, widowed, or never married; and they have one or more dependent children 
or other dependent relatives living in the family; and they pay more than half the expenses of the family. Individuals who are unmarried (never married, divorced, separated, or widowed) and have no dependents are assigned a tax filing status of single. In our TAXSIM simulation we follow the CPS conventions of assigning persons to tax filing units with the one exception of cohabitants who are not legally married.

Itemization. Depending on their level of taxable income, homeowners without a mortgage may or may not have been assigned the standard deduction. The TAXSIM model requires information on the amount of itemized deductions. We assume that all tax units, including married tax units, take the standard deduction. This assumption will undoubtedly overestimate the actual tax burden of tax units who itemized their deductions.

Dependents. The assignment of dependents is important for calculating the number of dependent exemptions per tax unit and thus estimating taxes. The tax code allows tax units to reduce their taxable income for each dependent person they claim to support. The CPS rules for defining dependents in a tax unit are that family members who are not a head or spouse are considered dependents if they are less than age 16 and have an annual income of less than $\$ 10,000$ or older than 16 and have an annual income of less than $\$ 5,000$. All family members are looked at to determine whether they can be considered dependents. Once dependency is established, dependents are assigned to the appropriate tax unit. For tax purposes, dependents with their own income are assigned to their own tax units because they must file their own tax returns.

However, because these individuals are dependents of their parents, they are still counted as exemptions within their parents' tax units. We use these same CPS rules, which approximate IRS rules, to determine dependent status in our TAXSIM estimates. 
Table 1B. List of TAXSIM Input Variables and Corresponding CPS Variables

\begin{tabular}{|c|c|c|}
\hline & TAXSIM Input Variables & CPS Tax Unit Input Variables \\
\hline 1 & Case ID (must be numeric) & Tax Unit ID number \\
\hline 2 & Tax year (4 digits) & Income year (survey year minus 1) \\
\hline 3 & $\begin{array}{l}\text { State (SOI codes. These run from } 1 \text { for Alabama } \\
\text { to } 51 \text { for Wyoming) }\end{array}$ & State of residence in survey year \\
\hline 4 & $\begin{array}{l}\text { Marital Status: } \\
\text { 1. single } \\
\text { 2. joint } \\
\text { 4. head of household } \\
\text { 8. single dependent on parents' return (no } \\
\text { personal exemption) }\end{array}$ & Provided in the CPS by RAND \\
\hline 5 & $\begin{array}{l}\text { Dependent Exemptions (usually children but can } \\
\text { be any age) }\end{array}$ & Created \\
\hline 6 & Age exemptions & $\begin{array}{l}\text { Number of taxpayers over } 65 \text { years of } \\
\text { age (maximum is } 2 \text { ) in tax unit }\end{array}$ \\
\hline 7 & $\begin{array}{l}\text { Wage and salary income of Taxpayer (include } \\
\text { self-employment) }\end{array}$ & $\begin{array}{l}\text { Labor income of primary earner in } \\
\text { tax unit }\end{array}$ \\
\hline 8 & $\begin{array}{l}\text { Wage and salary income of Spouse (include self- } \\
\text { employment) }\end{array}$ & $\begin{array}{l}\text { Labor income of secondary earner in } \\
\text { tax unit }\end{array}$ \\
\hline 9 & Dividend income & Dividend income in tax unit \\
\hline 10 & Other property income & $\begin{array}{l}\text { Includes interest, rent, alimony, } \\
\text { fellowships and other income not } \\
\text { above enumerated. This is the only } \\
\text { dollar amount that may be negative. }\end{array}$ \\
\hline 11 & Taxable Pensions & $\begin{array}{l}\text { Sum of other retirement income in } \\
\text { tax unit }\end{array}$ \\
\hline 12 & Gross Social Security Income & $\begin{array}{l}\text { Sum of Social Security income in tax } \\
\text { unit }\end{array}$ \\
\hline 13 & $\begin{array}{l}\text { Other non-taxable transfer Income such as } \\
\text { welfare, municipal bond interest, and child } \\
\text { support that would affect eligibility for state } \\
\text { property tax rebates but would not be taxable at } \\
\text { the federal level }\end{array}$ & $\begin{array}{l}\text { Sum SSI, VA pensions, worker's } \\
\text { compensation, AFDC, and other } \\
\text { welfare income in tax unit }\end{array}$ \\
\hline 14 & $\begin{array}{l}\text { Rent Paid (used only for calculating state property } \\
\text { tax rebates) }\end{array}$ & Set to zero \\
\hline 15 & Property taxes paid & Set to zero \\
\hline 16 & $\begin{array}{l}\text { Itemized deductions other than state income tax } \\
\text { and local property tax }\end{array}$ & Set to zero \\
\hline 17 & Child care expenses & Set to zero \\
\hline 18 & Unemployment compensation received & $\begin{array}{l}\text { Sum of unemployment compensation } \\
\text { in tax unit }\end{array}$ \\
\hline
\end{tabular}


Table 2B. Estimating Income Tax Burdens for Current Population Survey (CPS) Households

Using the National Bureau of Economic Research TAXSIM Model

PSID, TaxSim

$\mathrm{HH} \quad \mathrm{HH} \quad \mathrm{HH} \quad$ Total

Federal State Payroll HH

Taxes Taxes Taxes Tax

$\begin{array}{lllll}\mathbf{1 9 7 9} & \mathbf{2 , 9 6 1} & \mathbf{5 0 4} & \mathbf{9 2 2} & \mathbf{4 , 3 8 7} \\ 1980 & 3,456 & 552 & 991 & 5,000 \\ 1981 & 3,937 & 604 & 1,180 & 5,721 \\ 1982 & 3,767 & 628 & 1,233 & 5,630 \\ 1983 & 3,834 & 736 & 1,336 & 5,907\end{array}$

$1984 \quad 4,648 \quad 857 \quad 1,631 \quad 7,138$

$\begin{array}{lllll}1985 & 4,644 & 859 & 1,735 & 7,240\end{array}$

$\begin{array}{lllll}1986 & 4,937 & 902 & 1,862 & 7,705\end{array}$

$\begin{array}{lllll}1987 & 4,239 & 934 & 1,964 & 7,141\end{array}$

$1988 \quad 4,393 \quad 1,031 \quad 2,213 \quad 7,640$

$\begin{array}{lllll}1989 & 4,581 & 1,041 & 2,304 & 7,928\end{array}$

$\begin{array}{lllll}1990 & 4,769 & 1,101 & 2,468 & 8,342\end{array}$

$\begin{array}{lllll}1991 & 4,877 & 1,171 & 2,540 & 8,593\end{array}$

$\begin{array}{lllll}1992 & 5,173 & 1,254 & 2,669 & 9,107\end{array}$

$\begin{array}{lllll}1993 & 6,531 & 1,511 & 2,911 & 9,906\end{array}$

$\begin{array}{lllll}1994 & 6,342 & 1,491 & 2,990 & 10,009\end{array}$

$\begin{array}{lllll}1995 & 6,341 & 1,499 & 3,049 & 10,350\end{array}$

$1996 \quad 6,151 \quad 1,443 \quad 3,146 \quad 10,582$

$\begin{array}{llllll}1997 & -- & -- & -- & --\end{array}$

$\begin{array}{lllll}1998 & 6,727 & 1,704 & 3,329 & 11,760\end{array}$

$\begin{array}{lllll}1999 & -- & -- & -- & -- \\ 2000 & 8,394 & \mathbf{1 , 9 8 4} & \mathbf{3 , 6 4 2} & \mathbf{1 4 , 0 2 0}\end{array}$
CPS, provided by Unicon

$\mathrm{HH} \quad \mathrm{HH} \quad \mathrm{HH} \quad$ Total

Federal State Payroll HH

Taxes Taxes Taxes Tax

$\mathbf{2 , 8 6 5} \quad 548 \quad 1,007 \quad 4,420$

$\begin{array}{llll}3,222 & 612 & 1,047 & 4,881\end{array}$

$\begin{array}{llll}3,480 & 609 & 1,268 & 5,357\end{array}$

$\begin{array}{llll}3,393 & 661 & 1,341 & 5,395\end{array}$

$\begin{array}{llll}3,279 & 739 & 1,418 & 5,437\end{array}$

$\begin{array}{llll}3,533 & 829 & 1,559 & 5,921\end{array}$

$\begin{array}{llll}3,843 & 929 & 1,753 & 6,525\end{array}$

$\begin{array}{llll}4,200 & 1,012 & 1,880 & 7,092\end{array}$

$\begin{array}{llll}4,122 & 1,172 & 1,986 & 7,279\end{array}$

$\begin{array}{llll}4,195 & 1,190 & 2,195 & 7,579\end{array}$

$\begin{array}{llll}\mathbf{4 , 6 3 1} & \mathbf{1 , 4 1 5} & \mathbf{2 , 3 6 5} & \mathbf{8 , 4 1 1}\end{array}$

$\begin{array}{llll}4,671 & 1,430 & 2,467 & 8,567\end{array}$

$\begin{array}{llll}4,496 & 1,269 & 2,533 & 8,297\end{array}$

$\begin{array}{llll}4,556 & 1,335 & 2,601 & 8,492\end{array}$

$5,098 \quad 1,479 \quad 2,700 \quad 9,277$

$--$

$\begin{array}{llll}5,579 & 1,650 & 2,887 & 10,116\end{array}$

$\begin{array}{llll}5,932 & 1,764 & 3,012 & 10,708\end{array}$

$\begin{array}{llll}6,585 & 1,939 & 3,208 & 11,732\end{array}$

6,891

7,346

7,677
CPS, TaxSim, based on consistently top-coded income

$\mathrm{HH} \quad \mathrm{HH} \quad \mathrm{HH}$ Total

Federal State Payroll $\mathrm{HH}$

Taxes Taxes Taxes Tax

\section{$3,064 \quad 511 \quad 1,029 \quad 4,604$}

$3,491 \quad 547 \quad 1,111 \quad 5,149$

$4,111 \quad 603 \quad 1,309 \quad 6,023$

$4,152 \quad 660 \quad 1,374 \quad 6,187$

$4,042 \quad 755 \quad 1,455 \quad 6,252$

$4,557 \quad 841 \quad 1,643 \quad 7,041$

$\begin{array}{llll}4,878 & 870 & 1,757 & 7,504\end{array}$

$5,178 \quad 915 \quad 1,879 \quad 7,973$

$4,429 \quad 949 \quad 1,975 \quad 7,353$

$\begin{array}{llll}4,513 & 948 & 2,146 & 7,607\end{array}$

$\begin{array}{llll}4,956 & 1,063 & 2,307 & 8,326\end{array}$

$\begin{array}{llll}4,971 & 1,090 & 2,418 & 8,479\end{array}$

$4,907 \quad 1,124 \quad 2,479 \quad 8,511$

$4,914 \quad 1,182 \quad 2,545 \quad 8,642$

$5,224 \quad 1,245 \quad 2,643 \quad 9,111$

$--$

5,662

5,915

6,442

6,495

6,929

7,222
CPS, TaxSim, based on raw CPS public use income values

$\mathrm{HH} \quad \mathrm{HH} \quad \mathrm{HH}$ Total

Federal State Payroll $\mathrm{HH}$

Taxes Taxes Taxes Tax

$\begin{array}{llll}3,066 & 512 & 1,030 & 4,608\end{array}$

$3,495 \quad 547 \quad 1,112 \quad 5,154$

$4,118 \quad 604 \quad 1,310 \quad 6,032$

$4,158 \quad 661 \quad 1,375 \quad 6,194$

$4,050 \quad 756 \quad 1,456 \quad 6,262$

$\begin{array}{llll}4,565 & 842 & 1,643 & 7,050\end{array}$

$\begin{array}{llll}4,887 & 871 & 1,757 & 7,515\end{array}$

$\begin{array}{llll}5,187 & 917 & 1,880 & 7,983\end{array}$

$\begin{array}{llll}4,437 & 950 & 1,976 & 7,364\end{array}$

$\begin{array}{llll}4,521 & 950 \quad 2,148 \quad 7,619\end{array}$

$\begin{array}{llll}4,964 & 1,065 & 2,308 & 8,337\end{array}$

$4,981 \quad 1,092 \quad 2,419 \quad 8,493$

$4,917 \quad 1,127 \quad 2,481 \quad 8,525$

$4,923 \quad 1,185 \quad 2,547 \quad 8,655$

$5,232 \quad 1,247 \quad 2,644 \quad 9,123$

-- -- $\quad$-- $\quad$--

$6,452 \quad 1,477 \quad 2,876 \quad 10,805$

$6,812 \quad 1,527 \quad 2,998 \quad 11,338$

$\begin{array}{llll}7,506 & 1,647 \quad 3,156 & 12,309\end{array}$

$7,809 \quad 1,701 \quad 3,331 \quad 12,842$

$7,845 \quad 1,715 \quad 3,498 \quad 13,058$

$\mathbf{8 , 8 4 1} \quad 1,844 \quad 3,697 \quad 14,382$ 


\section{REFERENCES}

Artis, M.J., R.C. Bladen-Hovell and W. Zhang. 1995. "Turning points in the international business cycle: An analysis of the OECD leading indicators for the G7 countries," OECD Economic Studies 24: 125 -165.

Atkinson, A.B. 1983. The Economics of Inequality, 2nd edition. Oxford: Oxford University Press.

Atkinson, A.B., L. Rainwater, T. M. Smeeding. 1995. Income Distribution in OECD Countries: Evidence from the Luxembourg Income Study. (LIS). Social Policy Studies No. 18, OECD Paris, October.

Boskin, M.J., E.R. Dulberger, R.J. Gordon, Z. Griliches, and D.W. Jorgenson. 1996. Toward a More Accurate Measure of the Cost of Living. Final report to the Senate Finance Committee from the Advisory Commission to Study the Consumer Price Index, December 4, 1996. http://www.ssa.gov/history/reports/boskinrpt.html.

Burkhauser, Richard V., J.S. Butler, S. Feng, and A.J. Houtenville. 2004. "Long Term Trends in Earnings Inequality: What the CPS Can Tell Us.” Economics Letters, 82 (2), 295-299.

Burkhauser, R.V., B.A. Butrica, M.C. Daly, and D.R. Lillard. 2001. "The Cross-National Equivalent File: A Product of Cross-National Research.” In Irene Becker, Notburga Ott, and Gabriele Rolf (eds.) Soziale Sicherung In Einer Dynamischen Gesellschaft. Frankfurt, Germany: Campus Verlagi, pp. 354-376.

Burkhauser, R.V., K.A. Couch, A.J. Houtenville, and L. Rovba. 2004. "Income Inequality in the 1990s: Re-Forging a Lost Relationship?” Journal of Income Distribution, 12 (3-4), 8-35.

Burkhauser, R.V., A.C. Cutts, M.C. Daly, and S.P. Jenkins. 1999. "Testing the Significance of Income Distribution Changes Over the 1980s Business Cycle: A Cross-National Comparison.” Journal of Applied Econometrics, 14, 253-272. 
Burkhauser, R.V., S. Feng, and S.P. Jenkins 2006. “Using a P90/P10 Ratio to Measure Inequality Trends with the Public Use Current Population Survey: A View from Inside the Census Bureau Vaults.” Cornell Working Paper.

Burkhauser, R.V. and L. Rovba. 2005. "Income Inequality in the 1990s: Comparing the United States, Great Britain, and Germany.” Japanese Journal of Social Security, 4(1) (June 2005): 1-16.

Burkhauser, R.V., T.M. Smeeding, and J. Merz. 1996. "Relative Inequality and Poverty in Germany and the United States Using Alternative Equivalency Scales," The Review of Income and Wealth, 42(4) (December): 381-400.

DeNavas-Walt, C. and R. W. Cleveland. 2002. "Money Income in the United States: 2001," Current Population Reports, US Census Bureau (September).

Feng, S., R.V. Burkhauser, and J.S. Butler. 2005. "Levels and Long-Term Trends in Earning Inequality: Overcoming Current Population Survey Censoring Problems Using GB2 Distribution." Working Paper, Department of Policy Analysis and Management, Cornell University.

Foerster M. and M. d'Ercole M. 2005. Income distribution and Poverty in OECD Countries in the Second Half of 1990s. OECD Social, Employment and Migration Working Papers 22.

Couch, K. A. and M.C. Daly. 2004. “The Improving Relative Status of Black Men,” Journal of Income Distribution, 12 (3-4)

Fukawa, T. 2002. "Income Distribution and Retirement Income in Japan” The Japanese Journal of Social Security Policy, 1(1) (August): 27-36.

Goodman, A and A. Shephard. 2002. Inequality and Living Standards in Great Britain Some Facts, IFS. Briefing Note 19. http://www.ifs.org.uk/publications.php?publication_id=1768 
Jacobs D. 2000. Low Inequality with Low Redistribution? An Analysis of Income Distribution in Japan, South Korea and Taiwan Compared to Britain. Centre for Analysis of Social Exclusion No.33, London School of Economics.

Jones, A.F. Jr. and D. H. Weinberg. 2000, “The Changing Shape of the Nation's Income Distribution," Current Population Reports, US Census Bureau, (June).

Karoly, L. A. 1992. "Changes in the Distribution of Individual Earnings in the United States: 1967-1986.” Review of Income and Statistics, 74(1), 107-115.

Karoly, L.A., and G. Burtless. 1995. "Demographic Change, Rising Earnings Inequality, and the Distribution of Personal Well-Being, 1959-1989," Demography, 32 (3): 379-405.

Pen, J.. 1971. Income Distribution. New York: Praeger Publications.

Polivka, A. 1996. "Using Earnings Data from the Current Population Survey After the Redesign." Bureau of Labor Statistics Working Paper, No. 306.

Ryscavage, P. 1995. “A Surge in Growing Income Inequality?” Monthly Labor Review, August 1995: 51-61.

Saposnik, R. 1981. "Rank-Dominance in Income Distribution" Public Choice, 36 pp 147-151.

Saposnik, R. 1983. "On Evaluating Income Distributions: Rank Dominance, the Suppes-Sen Grading Principle of Justice and Pareto Optimality," Public Choice, 40: 329-36.

Silverman, B.W. 1986. Density Estimation for Statistics and Data Analysis. London: Chapman and Hall.

Smeeding T.M. 1997. US Income Inequality in a Cross National Perspective: Why Are We So Different? Luxembourg Income Study, Working Paper No.157. Tachibanaki, T. 1996. "Wage Determination and Distribution in Japan" Oxford University Press.

Tachibanaki, T. 2005. "Confronting Income Inequality in Japan: a Comparative Analysis of Causes, Consequences, and Reform.” Cambridge: MIT Press. 
Terasaki, Y. 2002. The Impact of Changes in Family Structure on Income Distribution in Japan, 1989-1997 Rising Inequality of Household Income Reconsidered. The Japanese Journal of Social Security Policy, 1(1) (August): S2-S16.

Vogel, E.F. 1979. Japan as Number One: Lessons for America. Cambridge: Harvard University Press. 
Table 1. Post-tax Post-transfer Household Size-Adjusted Income and Income Inequality, by Age in the United States, Great Britain, Germany, and Japan.

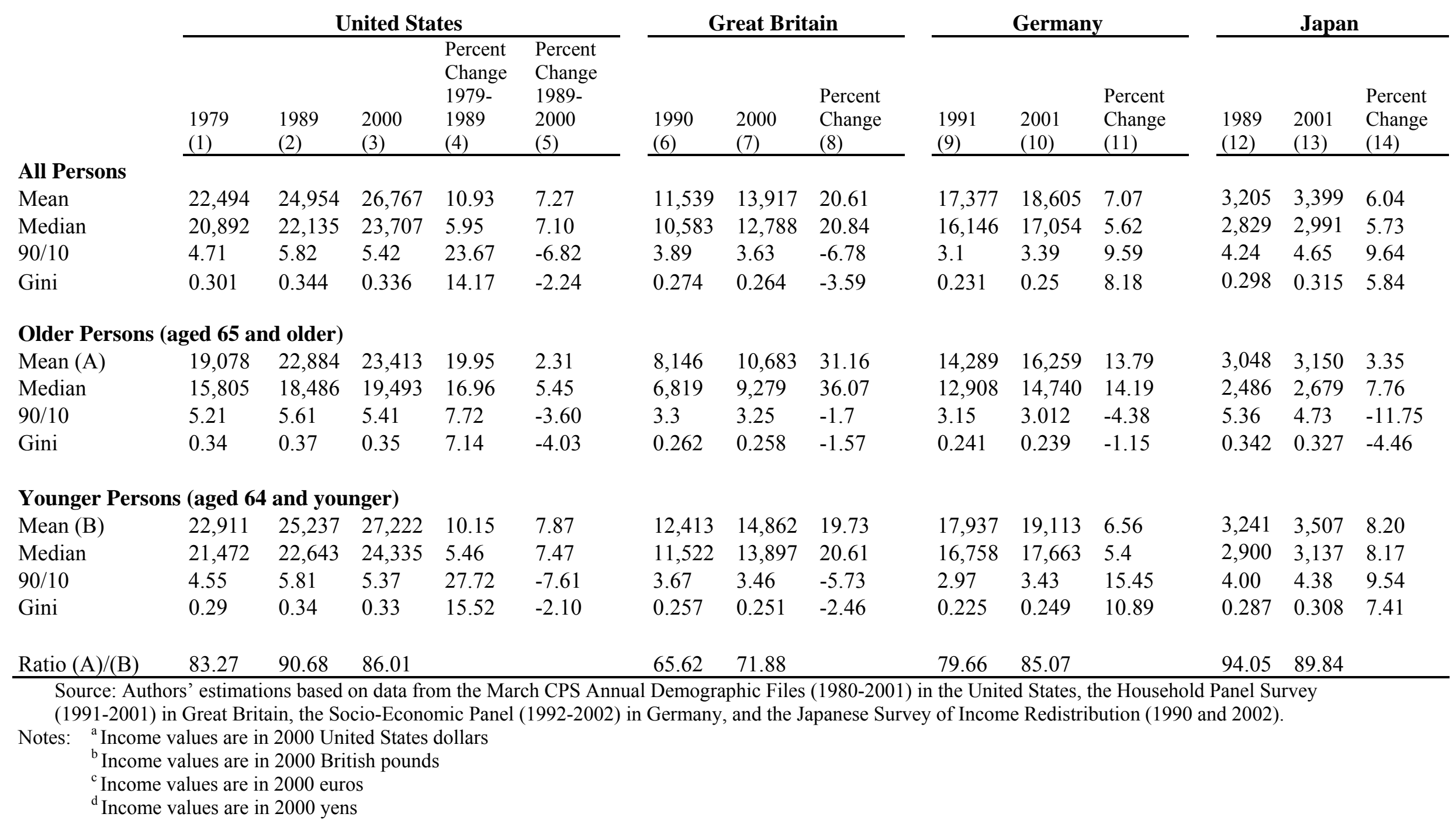


Table 2. Kolmogorov-Smirnov Test of Differences in Income Distributions Across Paired Years.

\begin{tabular}{|c|c|c|c|c|c|c|}
\hline & \multicolumn{3}{|c|}{ United States } & \multirow{3}{*}{\begin{tabular}{l}
\multicolumn{1}{c}{$\begin{array}{c}\text { Great } \\
\text { Britain }\end{array}$} \\
1990 \\
versus \\
2000
\end{tabular}} & \multirow{3}{*}{$\begin{array}{l}\text { Germany } \\
1991 \\
\text { versus } \\
2001\end{array}$} & \multirow{3}{*}{\begin{tabular}{l}
\multicolumn{1}{c}{ Japan } \\
1989 \\
versus \\
2001
\end{tabular}} \\
\hline & $\begin{array}{l}1979 \\
\text { versus }\end{array}$ & 1989 & $\begin{array}{l}1979 \\
\text { versus }\end{array}$ & & & \\
\hline Group & $\begin{array}{l}\text { versus } \\
1989 \\
\end{array}$ & $\begin{array}{l}\text { versus } \\
2000\end{array}$ & $\begin{array}{l}\text { versus } \\
2000\end{array}$ & & & \\
\hline Total Population & 5.85 & 3.9 & 5.95 & 7.982 & 21.732 & 8.652 \\
\hline Aged 64 and younger & 4.75 & 2.85 & 4.675 & 3.634 & 22.692 & 6.954 \\
\hline Aged 65 and older & 2.295 & 2.5 & 3.58 & 15.397 & 8.786 & 4.845 \\
\hline
\end{tabular}

Source: Authors' estimations based on data from the March CPS Annual Demographic Files (1980-2001) in the United States, the Household Panel Survey (1991-2001) in Great Britain, the Socio-Economic Panel (1992-2002) in Germany, and the Japanese Survey of Income Redistribution (1990 and 2002).

Note: All test statistics are significant at 1 percent level. 
Table 3. Change in the Distribution of the Population Mass over Paired Years in the United States, Germany, and Japan.

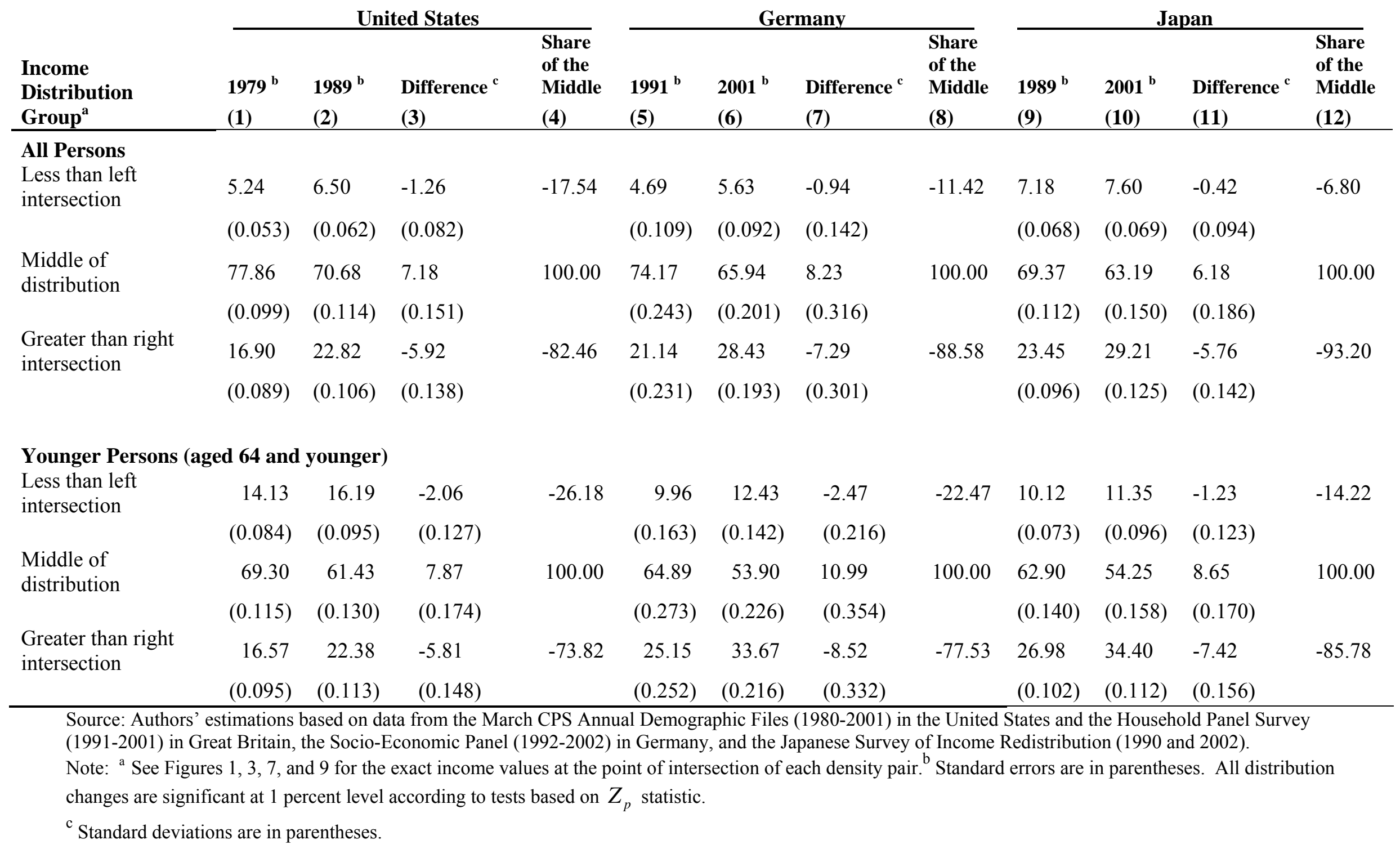


Figure 1. Total United States Income Distributions in Peak Business Cycle Years.

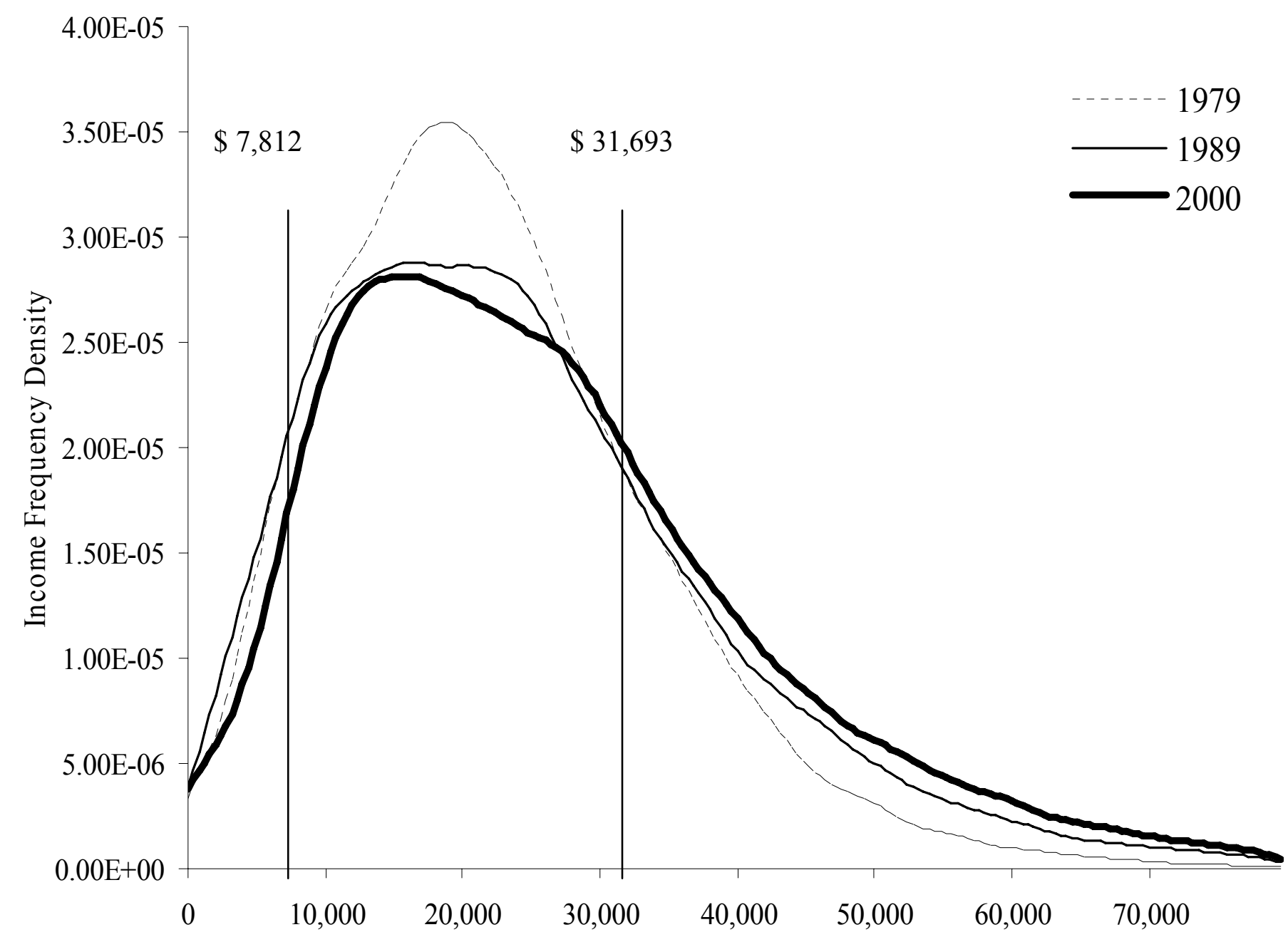

Post-Tax Post-Transfer Household Sized-Adjusted Income, 2000 Dollars

Source: Authors' estimations based on data from the March CPS Annual Demographic Files, 1980, 1990, and 2001. 
Figure 2. United States Income Distributions for Older Persons in Peak Business Cycle Years.

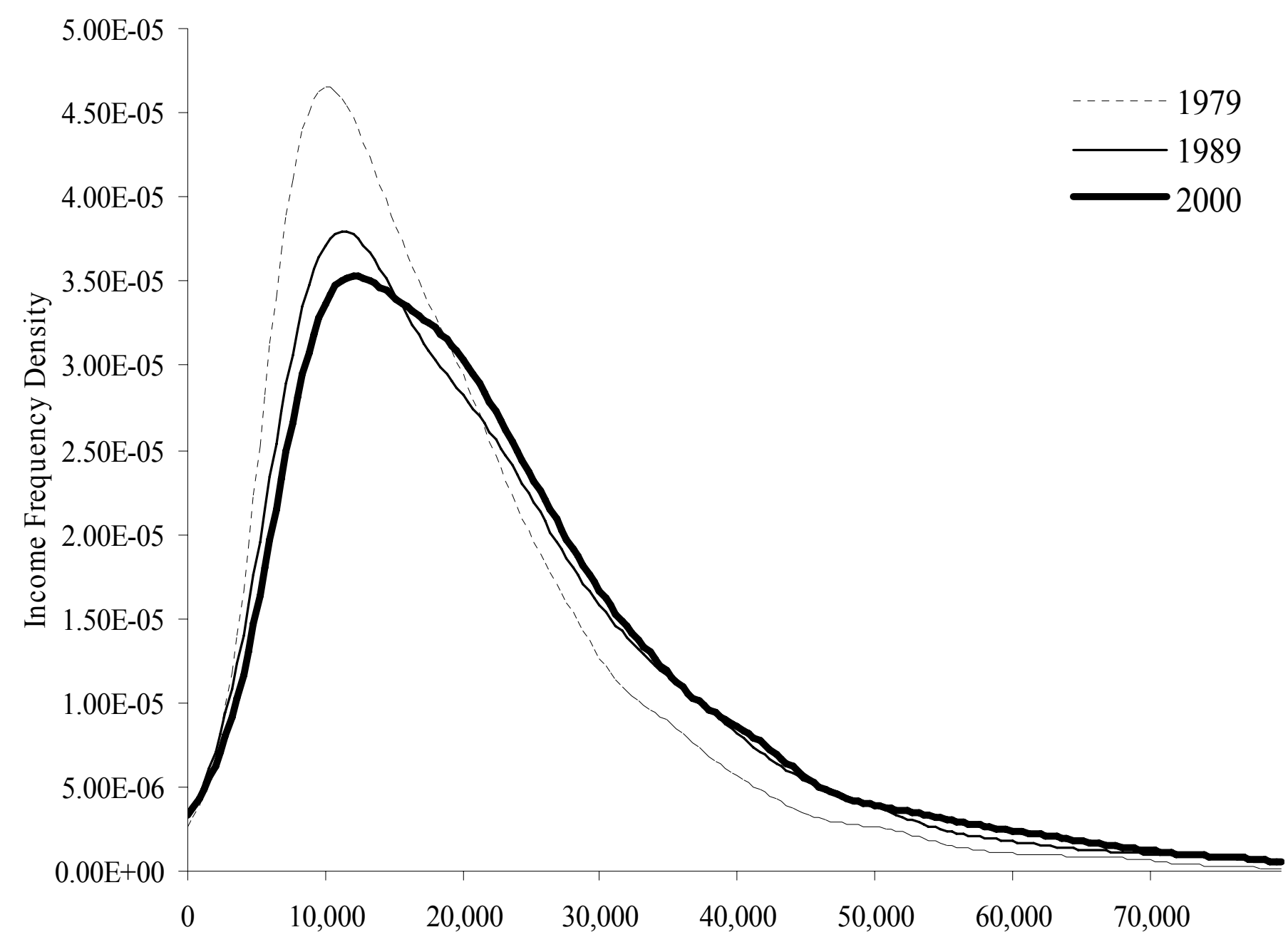

Post-Tax Post-Transfer Household Size-Adjusted Income, 2000 Dollars

Source: Authors' estimations based on data from the March CPS Annual Demographic Files, 1980, 1990, and 2001. 
Figure 3. United States Income Distributions for Younger Persons in Peak Business Cycle Years.

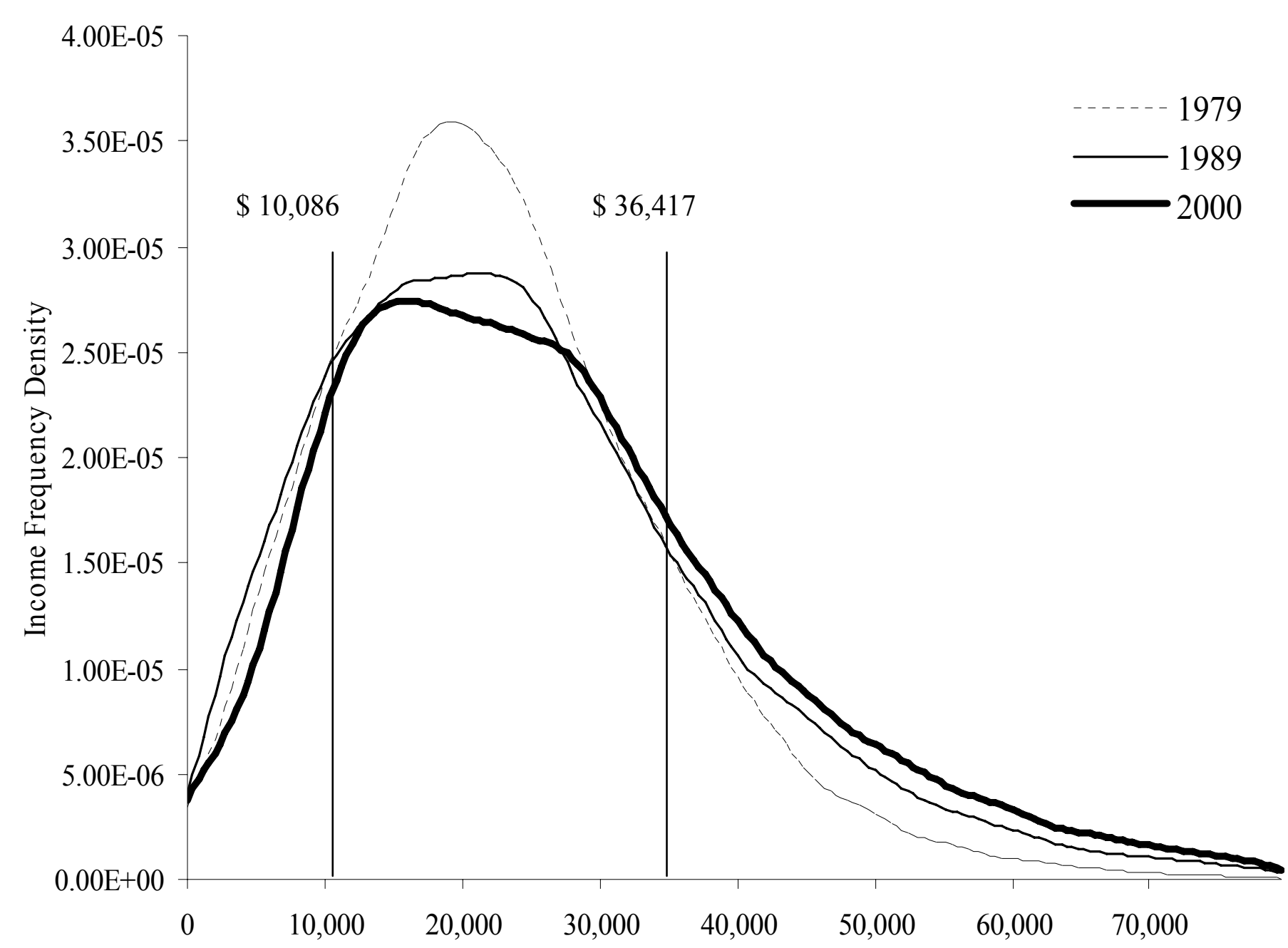

Post-Tax Post-Transfer Household Size-Adjusted Income, 2000 Dollars

Source: Authors' estimations based on data from the March CPS Annual Demographic Files, 1980, 1990, and 2001. 
Figure 4. Total Great Britain Income Distributions in Peak Business Cycle Years.

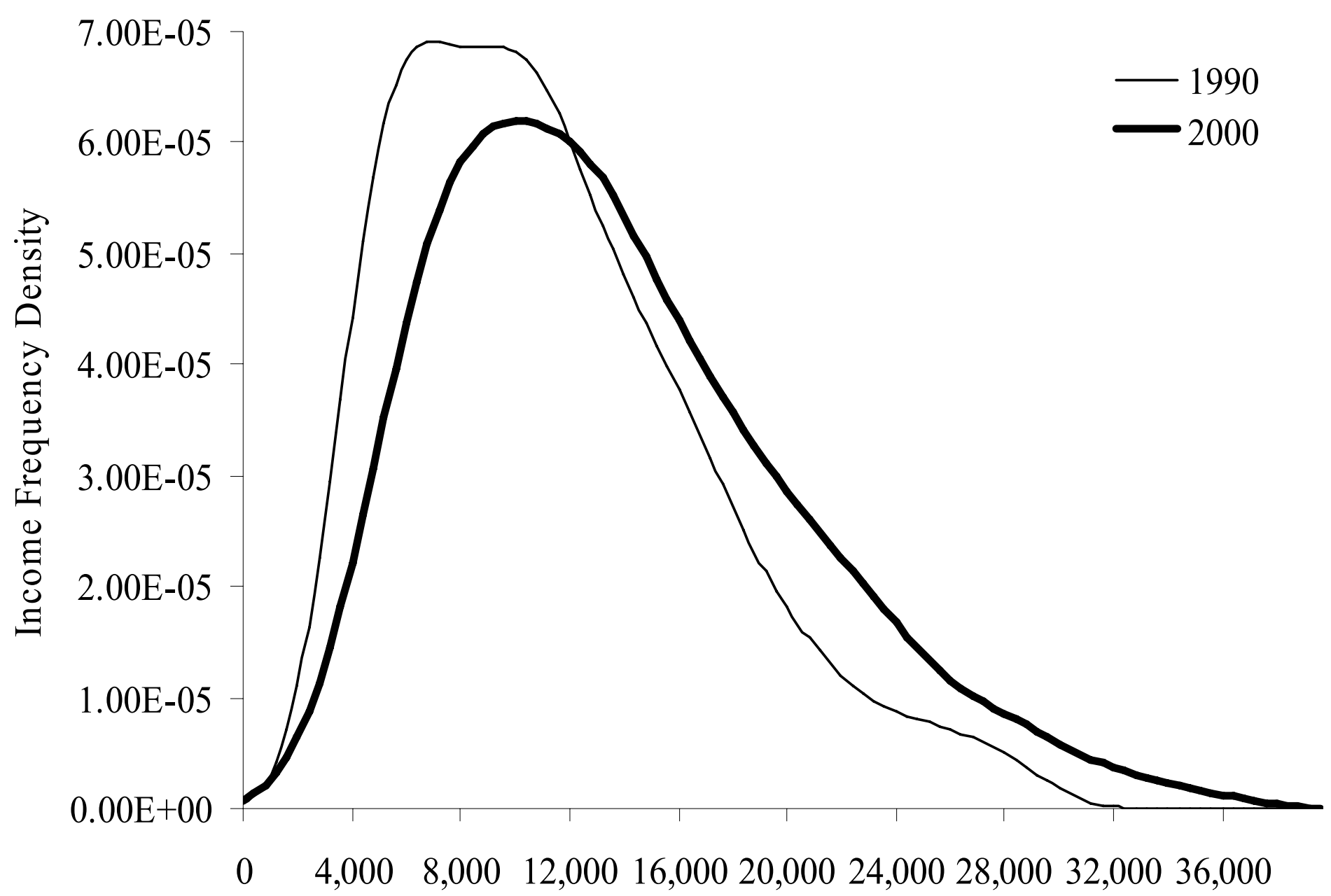

Post-Tax Post-Transfer Household Sized-Adjusted Income, 2000 Pounds

Source: Authors' estimations based on data from the British Household Panel Survey, 1991 and 2001. 
Figure 5. Great Britain Income Distributions for Older Persons in Peak Business Cycle Years.

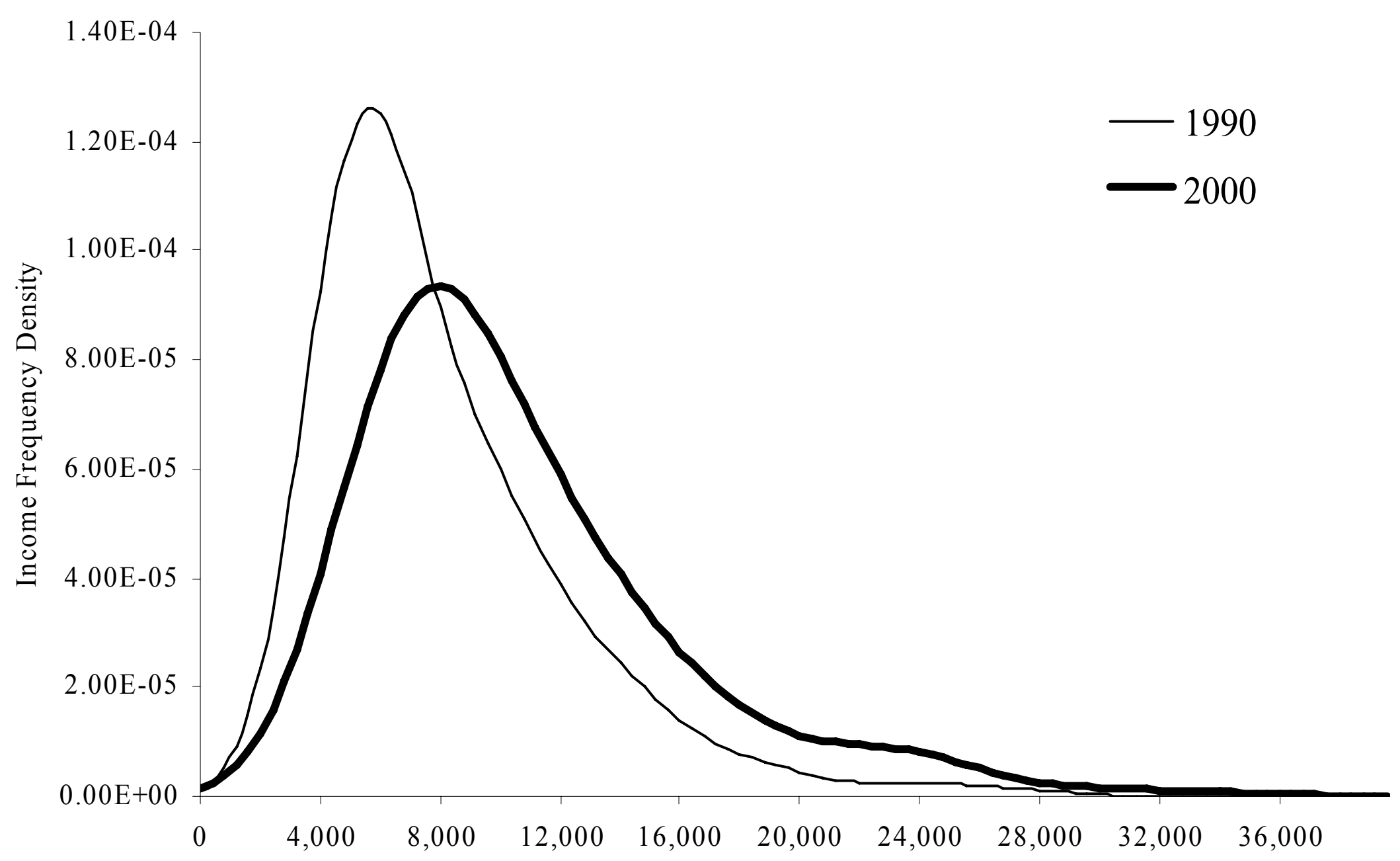

Post-Tax Post-Transfer Household Size-Adjusted Income, 2000 Pounds

Source: Authors' estimations based on data from the British Household Panel Survey, 1991 and 2001. 
Figure 6. Great Britain Income Distributions for Younger Persons in Peak Business Cycle Years.

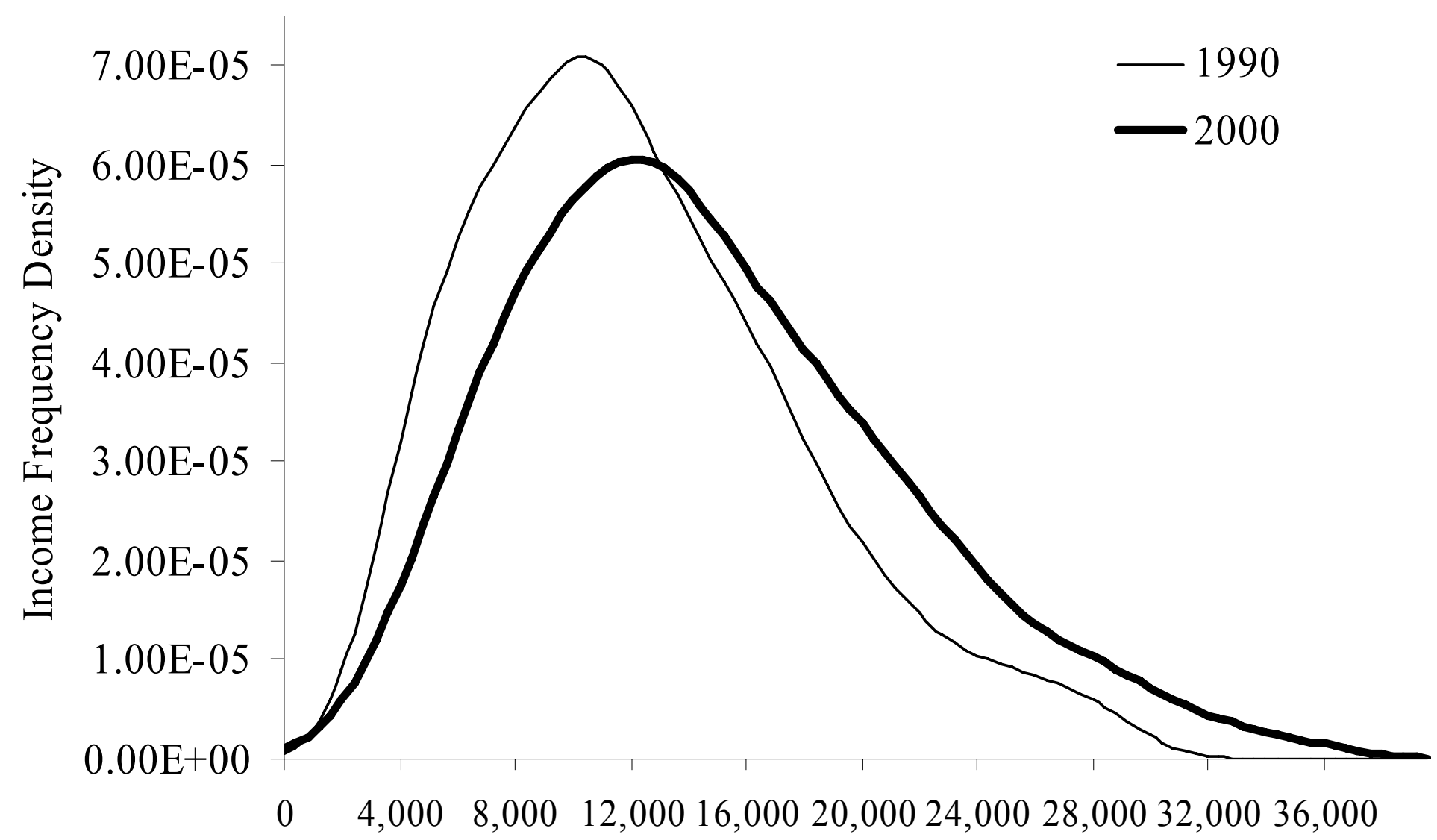

Post-Tax Post-Transfer Household Size-Adjusted Income, 2000 Pounds

Source: Authors' estimations based on data from the British Household Panel Survey, 1991 and 2001. 
Figure 7. Total German Income Distribution in Peak Business Cycle Years.

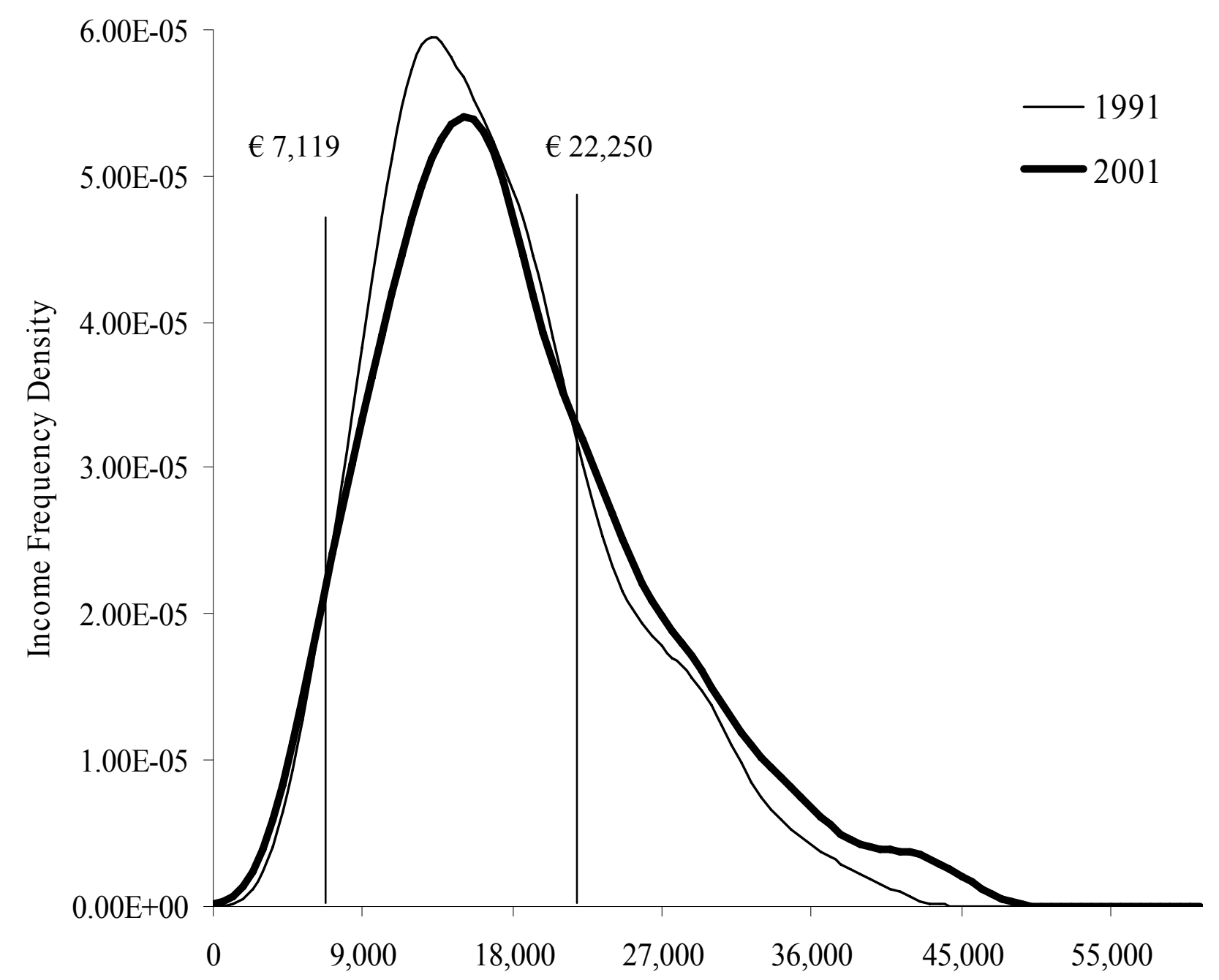

Post-Tax Post-Transfer Household Sized-Adjusted Income, 2000 Euros

Source: Authors' estimations based on data from the German Socio-Economic Panel, 1992 and 2002. 
Figure 8. German Income Distributions for Older Persons in Peak Business Cycle Years.

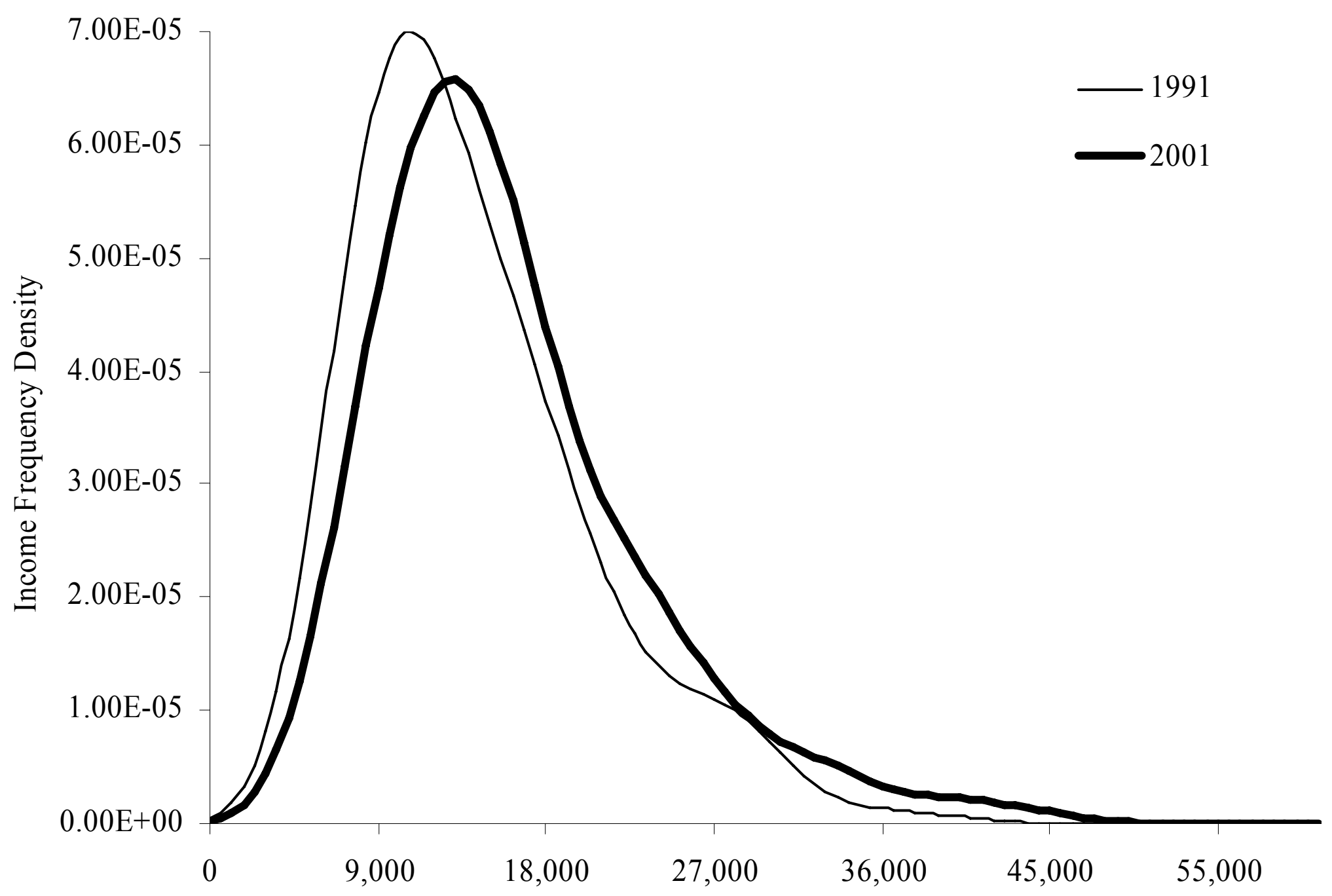

Post-Tax Post-Transfer Household Income, 2000 Euros

Source: Authors' estimations based on data from the German Socio-Economic Panel, 1992 and 2002. 
Figure 9. German Income Distributions for Younger Persons in Peak Business Cycle Years.

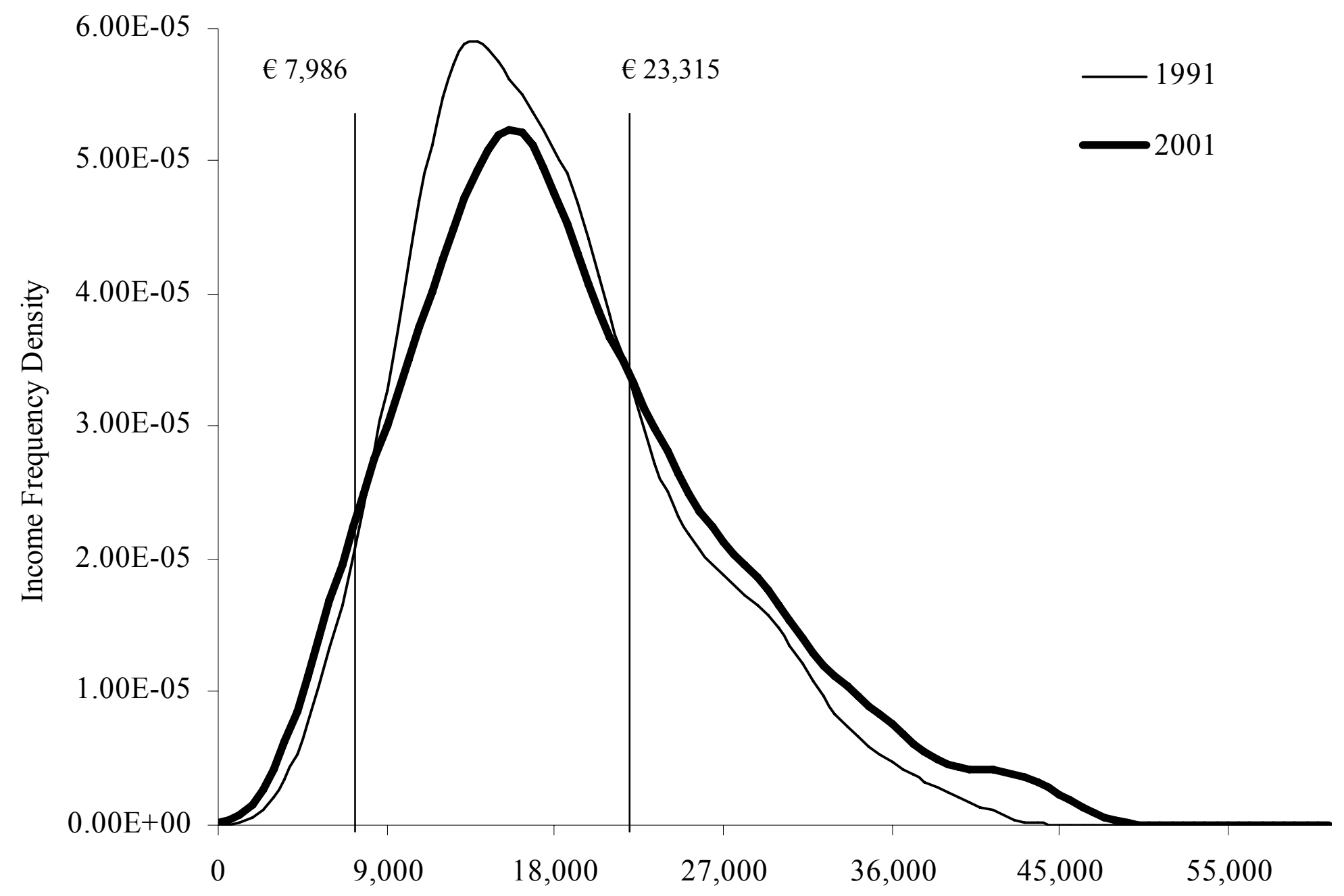

Post-Tax Post-Transfer Household Income, 2000 Euros

Source: Authors' estimations based on data from the German Socio-Economic Panel, 1992 and 2002. 
Figure 10. Japan, Total Income Distribution in Peak Business Cycle Years.

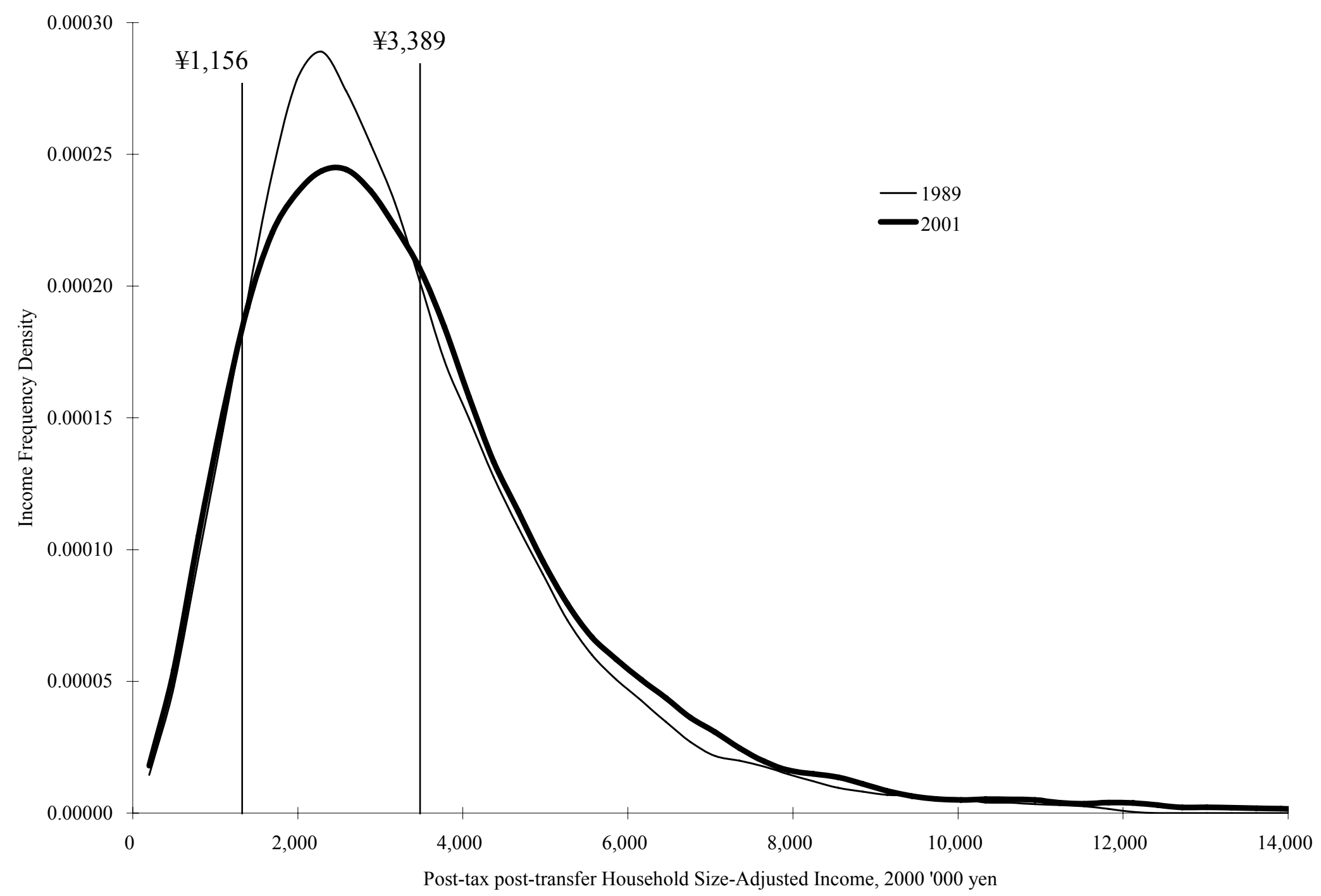

Source: Authors' estimations based on data from the Japanese Survey of Income Redistribution, 1990 and 2002. 
Figure 11. Japan, Income Distributions for Older Persons in Peak Business Cycle Years.

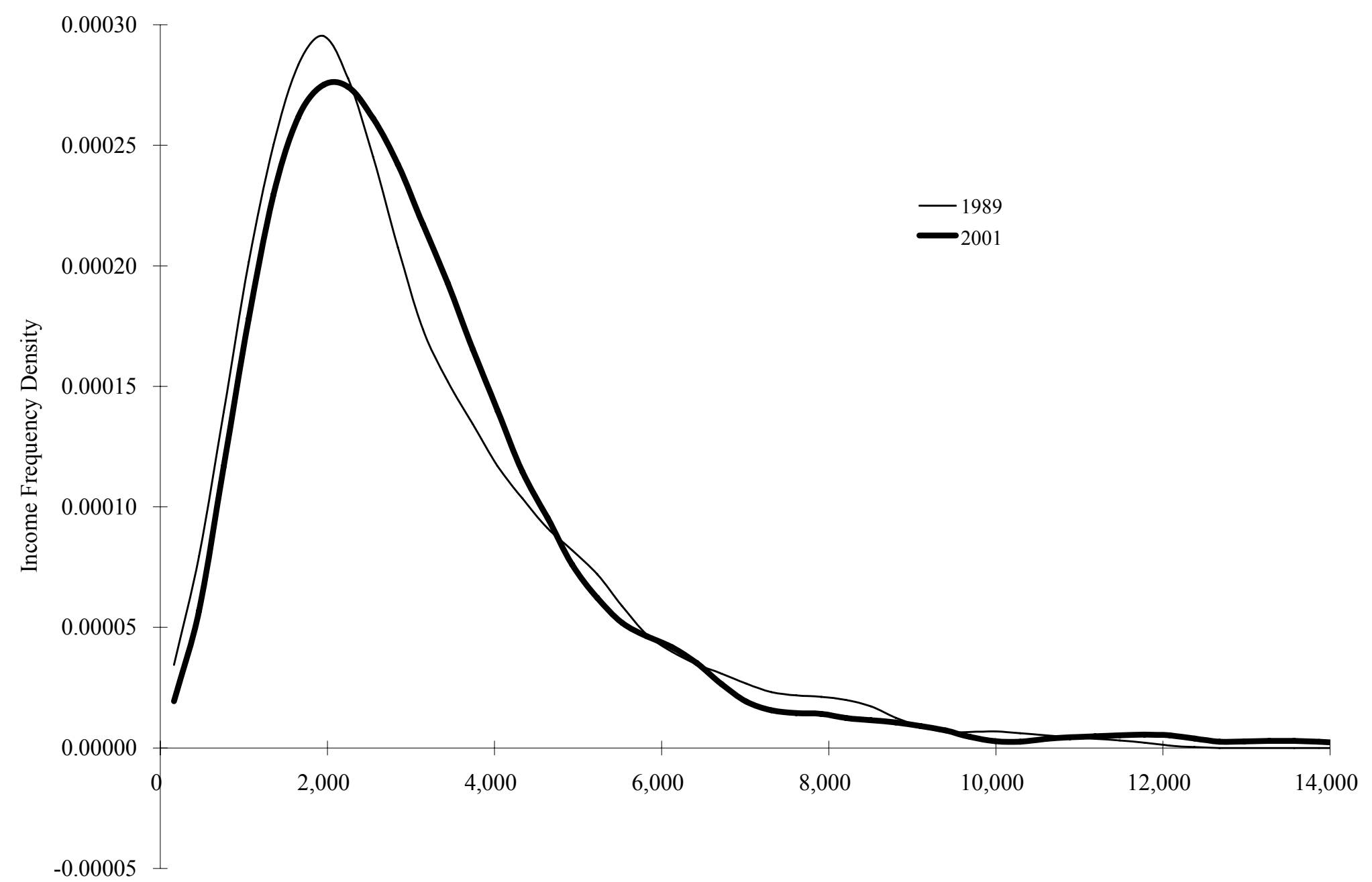

Post-tax post-transfer Household Size-Adjusted Income, 2000 '000yen

Source: Authors' estimations based on data from the Japanese Survey of Income Redistribution, 1990 and 2002. 
Figure 12. Japan, Income Distributions for Younger Persons in Peak Business Cycle Years.

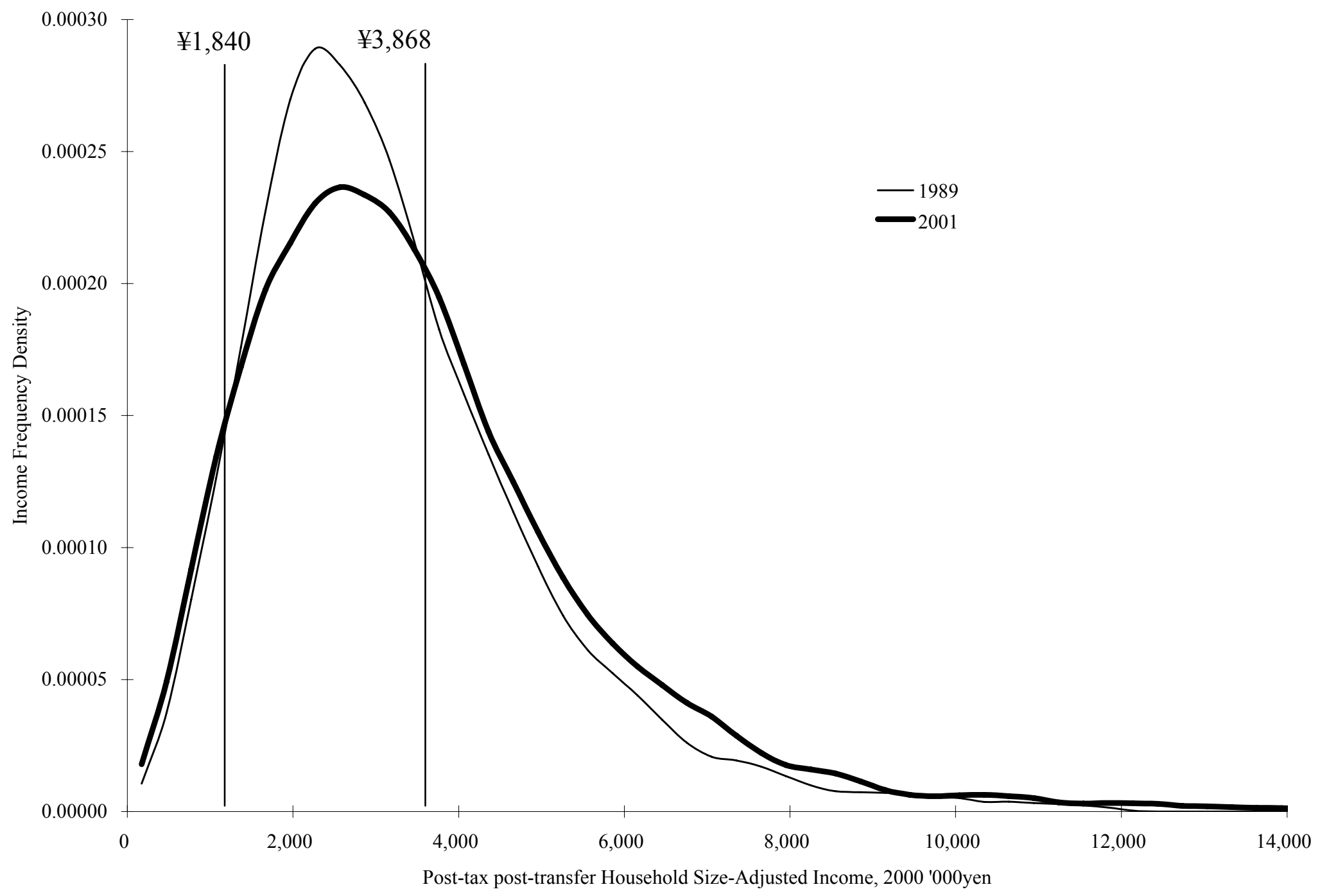

Source: Authors' estimations based on data from the Japanese Survey of Income Redistribution, 1990 and 2002. 


\section{Endnotes}

1. In the United States Current Population Survey, one can choose two methods to define an economic sharing unit. The family (all married or blood relatives who live in a common dwelling) or the household (all residents living in a common dwelling). These are the sharing units most often used by those estimating income inequality or poverty rates in the United States. Income within the sharing unit is assumed to be shared equally and some degree of returns to scale in the use of that income is assumed to be experienced by those who live together. Each individual in the sharing unit is then assigned a family or household size-adjusted income value. Burkhauser, Crews, Daly and Jenkins (1999) show that changes found by researchers in the distribution of income in the 1980s are similar using either a family or household sharing unit. We use the household unit as our sharing unit for the United States Current Population Survey. We use an expanded family sharing unit for the BHPS and GSOEP, which in addition to all married and blood relatives also includes cohabitators. But for ease of explication in this paper, we will call this sharing unit a "household." In the Japanese Survey of Income Redistribution, household is defined in a manner similar to the CPS - as all persons sharing the same housing unit, regardless of any familial relationship. Karoly (1992) and Karoly and Burtless (1995) use a similar strategy for the United States. The use of a household sharing unit is most common in cross-national studies. See Atkinson (1983), Atkinson, Rainwater, and Smeeding (1995), Smeeding (1997) and Foerster and d'Ercole (2005).

2 The starting and ending years of a business cycle are somewhat arbitrary. Rather then define them directly by changes in macroeconomic growth, we use peaks in income which will, in general, lag macroeconomic growth. This rule is straightforward in the United States and 
Great Britain where there are distinguishable peak years in average income. For Germany, income years 1991 and 1992 are similar. We chose 1991, though its average income was slightly lower than 1992, since it was closer to the peak year as defined using standard macroeconomic growth data. In Japan, differences in average income were much less pronounced. We chose 1989 and 2001 because they roughly correspond to peak years based on OECD methodology using a composite index of wage and salary income, employment, the industrial production index, manufacturing and trade sales, and quarterly gross domestic product. (See: Artis, Bladen-Hovell and Zhang, 1995). Our findings are not sensitive to reasonable changes to the peak years we choose to compare. While we have calculated average after-tax income and income inequality for all years in our study, here we focus on similar years in the business cycle. (Tables with mean and median income values and income inequality measures for all years are available from authors upon request.

3. We measure the size-adjusted income of all people residing in households in the CPS. But our unit of analysis is the person. Younger and older persons may live in the same household. In this case, they will receive the same household size-adjusted income value but that value will be included in the average for the age group of the individual.

4. Feng, Burkhauser and Butler (2005) show that a rule-of thumb trimming of the top 2 percent of the public use version of the CPS yields population samples whose levels and trends in wage earnings inequality are similar to those using the consistently top coded methods used here. See endnote 6 for a fuller discussion of this procedure. 
5. The formula used for this calculation is $Y_{a}=Y_{u} / F^{\theta}$. Here, $Y_{\mathrm{a}}$ is the adjusted household income used in the analysis. $\mathrm{Yu}$ is the unadjusted household income. $\mathrm{F}$ is household size. $\theta$ is the adjustment for household size. We assume $\theta=0.5$. As discussed in Karoly and Burtless (1995, p. 382), this implies that a four person household needs twice as much income as a one person household to attain the same level of consumption.

6 Boskin, Dulberger, Gordon, Grilliches, and Jorgenson (1996) offer the most systematic criticism of the CPI-X used in most measures of economic well-being in the United States and propose alternative indices for the 1980s that are between 1.0 and 1.5 percentage points below the CPI-X. While using alternative cost-of-living measures affects the magnitude of our results, (e.g., a lower CPI will increase the real gains in economic well-being over time), they do not alter our major points.

7. Burkhauser, Butler, Feng and Houtenville (2004) argue that despite the changes in the methods the Census Bureau has used to collect and report earnings between 1975 and 2001 (see Ryscavage 1995, Polivka 1996, and Jones and Weinberg 2000) in the March CPS data, these data can be used to consistently estimate trends in earnings inequality. Burkhauser, Couch, Houtenville and Rovba (2004) extend the top-coding procedure Burkhauser, Butler, Feng and Houtenville (2004) used to capture earnings to obtain household size-adjusted income. We use those same procedures here for post-tax post-transfer income. Our income measure produces Gini coefficients that are significantly lower than those for the full sample since we are systematically cutting off the upper tail of the distribution of income in all years, but as Burkhauser, Couch, Houtenville and Rovba (2004) show, there is no significant difference in the trends between the Gini coefficients produced by the Census Bureau based 
on their internal CPS data and our Gini coefficients both before the major change in their top coding rules in 1992 and afterward. (See: DeNavas-Walt and Cleveland 2002, p.20-22, Table A-3, for internal Census Gini values.) Results in Burkhauser, Couch, Houtenville and Rovba (2004) mirror the results found by Burkhauser, Butler, Feng and Houtenville (2004) with respect to earnings. Hence we believe our income trends provide an accurate measure of income inequality in the United States between 1979 and 2000.

8. Burkhauser, Crews, Daly and Jenkins (1999) used data from the CPS to look at how the pretax, post-transfer income distribution changed over the 1980s business cycle in the United States and data from the Households below Average Income sub file of the United Kingdom Family Expenditure Survey to do the same for the United Kingdom over their 1980s business cycle. We use a consistently top coded version of the CPS data to replicate and extend their findings for the United States here as well as the finding of Burkhauser, Couch, Houtenville and Rovba (2004) for the 1990s business cycle using post-tax, post-transfer income. Our data for Great Britain comes from the BHPS whose first income year is 1991. Burkhauser, Crews, Daly and Jenkins (1999) found that pre-tax, post-transfer income inequality in both the United States and the United Kingdom increased over this period with the middle mass of the distribution falling into the two tails. But in both countries, the vast majority of the declining middle mass spilled to the right and became richer.

9 First order stochastic dominance is formally defined as follows: Consider two income distributions $\mathbf{y}_{1}$ and $\mathbf{y}_{2}$ with cumulative distribution functions (CDFs) $\mathrm{F}\left(\mathbf{y}_{1}\right)$ and $\mathrm{F}\left(\mathbf{y}_{2}\right)$. If $\mathrm{F}\left(\mathbf{y}_{1}\right)$ lies nowhere above and at least somewhere below $F\left(\mathbf{y}_{2}\right)$ then distribution $\mathbf{y}_{1}$ displays first order stochastic dominance over distribution $\mathbf{y}_{2}: F\left(\mathbf{y}_{1}\right) \leq F\left(\mathbf{y}_{2}\right)$ for all y. Hence in distribution $\mathbf{y}_{1}$ there are no more individuals with income less than a given income level than in distribution 
y2, for all levels of income. We can express this in an alternative way using the inverse function $\mathbf{y}=\mathrm{F}^{-1}(\mathbf{p})$ where $\mathrm{p}$ is the share of the population with income less than a given income level: first order dominance is attained if $\mathrm{F}_{1}^{-1}(\mathbf{p}) \geq \mathrm{F}_{2}^{-1}(\mathbf{p})$ for all $\mathrm{p}$. The inverse function $\mathrm{F}^{-1}(\mathbf{p})$ is known as a Pen's Parade (Pen, 1971), which simply plots incomes against cumulative population, usually using ranked income quantiles. The dominant distribution is one whose Parade lies nowhere below and at least somewhere above the other. First order stochastic dominance of distribution $\mathbf{y}_{1}$ over $\mathbf{y}_{2}$ implies that any social welfare function that is increasing in income, will record higher levels of welfare in distribution $\mathbf{y}_{1}$ than in distribution $\mathbf{y} 2$ (Saposnik, 1981, 1983).

10. The proportions $\hat{p}$ can be estimated from the kernel density estimates or directly from the data. We have used the latter method in order to avoid complicated reliance on the asymptotic properties of the kernel estimators. Standard errors for the estimated population proportions are also included and are calculated according to $s_{p}=\sqrt{\hat{p}(1-\hat{p})\left(\frac{1}{n^{2}} \sum_{i=1}^{n} w_{i}^{2}\right)}$, where $\hat{p}$ is the estimated proportion of interest.

11. See Burkhauser, Couch, Houtenville and Rovba (2004) and Couch and Daly (2004) for a thorough review of literature on this issue. The trends in Great Britain appear to be similar to that in the United States (see Goodman and Shephard, 2002 for a detailed discussion). 